WORKING PAPER $\cdot$ NO. 2020-55

\title{
Income, Liquidity, and the Consumption Response to the 2020 Economic Stimulus Payments
}

Scott R. Baker, R.A. Farrokhnia, Steffen Meyer, Michaela Pagel, and Constantine Yannelis MAY 2020

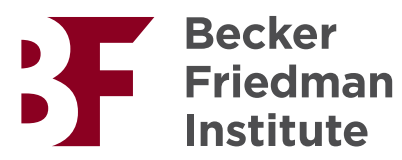




\title{
Income, Liquidity, and the Consumption Response to the 2020 Economic Stimulus Payments*
}

\author{
Scott R. Baker ${ }^{\dagger} \quad$ R.A. Farrokhnia ${ }^{\ddagger} \quad$ Steffen Meyer ${ }^{\S}$ \\ Michaela Pagel ${ }^{\top}$ Constantine Yannelis ${ }^{\|}$
}

May 25, 2020

\begin{abstract}
The 2020 CARES Act directed cash payments to households. We analyze households' spending responses using high-frequency transaction data from a FinTech, exploring heterogeneity by income levels, recent income declines, and liquidity. Households respond rapidly to receipt of stimulus payments, with spending increasing by $\$ 0.30$ per dollar of stimulus during the first month. Households with lower incomes, greater income drops, and lower levels of liquidity display stronger responses highlighting the importance of targeting. Liquidity plays the most important role, with no observed spending response for households with high levels of bank account balances. Relative to the effects of previous economic stimulus programs in 2001 and 2008, we see larger and faster effects overall, smaller increases in durables spending, and larger increases in spending on food, likely reflecting the impact of shelter-in-place orders and supply disruptions. Additionally, we see increases in payments like rents, mortgages, and credit cards reflecting a short-term debt overhang. We formally show that these differences can make direct payments less effective in stimulating aggregate consumption.
\end{abstract}

JEL Classification: D14, E21, G51

Keywords: Household Finance, Consumption, COVID-19, Stimulus, MPC, Transaction Data

\footnotetext{
*The most up-to-date version of this paper is available at Columbia Fintech. The authors wish to thank Sylvain Catherine, Arpit Gupta, Jonathan Parker and Joe Vavra for helpful discussion and comments as well as seminar participants at the MoFiR Banking Workshop, the Toulouse School of Economics, Columbia Graduate School of Business, the University of Chicago Booth School of Business and the Federal Reserve Bank of Philadelphia. Constantine Yannelis is grateful to the Fama Miller Center for generous financial support. R.A. Farrokhnia is grateful to Advanced Projects and Applied Research in Fintech at Columbia Business School for support. We would like to thank Suwen Ge, Spyros Kypraios, Rebecca Liu, and Sharada Sridhar for excellent research assistance. We are grateful to SaverLife for providing data access. This draft is preliminary and comments are welcome.

${ }^{\dagger}$ Northwestern University, Kellogg, NBER; s-baker@kellogg.northwestern.edu

${ }^{\ddagger}$ Columbia Business School, Columbia Engineering School; farrokhnia@gsb.columbia.edu

${ }^{\S}$ University of Southern Denmark (SDU) and Danish Finance Institute (DFI); stme@ sam.sdu.dk

${ }^{\top}$ Columbia Business School, NBER, and CEPR; mpagel@ columbia.edu

"University of Chicago Booth School of Business, NBER; constantine.yannelis@chicagobooth.edu
} 


\section{Introduction}

One of the tools used by governments in response to recessions is cash payments to households. These payments are meant to ultimately alleviate the effects of a recession and stimulate the economy through a multiplier effect, i.e., by increasing households' consumption which then translates to more production and employment. The effectiveness of these payments relies on households' marginal propensities to consume, or MPCs, out of these stimulus payments.

In this paper, we estimate households' MPCs in response to the 2020 CARES Act stimulus payments using data from a non-profit FinTech. We also look at how these MPCs vary with household characteristics, such as income, income declines, and cash on hand. Finally, we describe how household MPCs vary across categories of consumption and how these categorical responses differed from those seen in previous recessions. Understanding these MPCs is key to targeting policies to households where effects will be largest, as well as testing between different models of household consumption behavior.

MPCs are particularly important to both policy and economic theory as they determine fiscal multipliers in a wide class of models. More specifically, heterogeneity in MPCs impacts which households are most responsive to stimulus payments. In turn, targetting can have large impacts on the effectiveness of stimulus payments on consumption and the aggregate economy. This paper shows that liquidity is a key determinant of MPC heterogeneity during this recession, with highly liquid households showing no response to stimulus payments.

We explore responses to stimulus payments and individual heterogeneity in MPCs by using high frequency transaction data from SaverLife, a non-profit helping working families develop long-term savings habits and meet financial goals. Individuals can link their accounts to the service, and we have access to de-identified bank account transactions and balances data from August 2016 to April 2020 for these users. The fact that we observe inflows and outflows from individual accounts as well as balances in this dataset allows us to explore heterogeneity in levels of income, changes in income, and liquidity.

We use this high-frequency detailed data to look at stimulus payments distributed by mid-April 2020. The first stimulus payments were made on April 9th via direct deposit from the IRS, and we can observe spending daily before and after stimulus payments are made. The fact that we observe 
payment amounts and the exact timing of payments allows us to identify MPCs. We see sharp and immediate responses to the stimulus payments, and continued elevated spending even ten days after payments were received. Within ten days, users spend 29 cents of every dollar received in stimulus payments. The largest increases in spending are on food, non-durables, and rent and bill payments. In contrast to the 2008 stimulus payments (Parker, Souleles, Johnson and McClelland, 2013), there is relatively little increase in spending on durables.

We exploit the fact that we observe paychecks and account balances to explore heterogeneity. Greater income, larger income drops, and less liquidity are all associated with larger MPCs with liquidity being the strongest predictor of MPCs. Individuals with less than $\$ 500$ in their accounts spend over one third of their stimulus payments within ten days - 36 cents out of every dollar - while we observe no response for individuals with more than $\$ 3,000$ in their accounts. These results are important in terms of targeting stimulus policies towards groups most impacted by them. The theory behind stimulus payments rests on multipliers, which in turn are, in most models, determined by MPCs. The results of this study suggest that targeting stimulus payments to households with low levels of liquidity in a type of recession where large sectors of the economy are shut down will have the largest effects on MPCs, and hence on fiscal multipliers.

We then consider a simple macroeconomic model that illustrates two reasons that untargetted fiscal stimulus payments in environments like the 2020 COVID-19 epidemic are less effective than the payments in response to the 2001 and 2008 economic downturns. We have a three-sector model, sector 1 are large food firms, sector 2 are restaurants/services/hospitality that are shutdown, and sector 3 are all other consumption goods including durables. Additionally, agents that work in sectors 1 and 2 borrow from agents that work in sector 3 as the initial condition. In turn, sector 2 shuts down due to a pandemic and we obtain the following results.

First, agents in all sectors cannot consume in sector 2 so that no stimulus payments flow into sector 2 that would increase employment and wages in that sector. But, sector 2 agents are the poorest agents with the highest MPCs out of their income. Second, agents in sector 2 choose to accumulate more debt in period 2 planning to repay it with their stimulus payment. In turn, sector 2 agents have to repay their debt which implies that the stimulus payment goes to agents in sector 3 that have the smallest MPC out of their income. In summary, in this economy, workers will spend their stimulus payment on mortgages and loan repayments as well as non-durable necessary 
consumption (sector 1) which implies that the cash flows to agents with less high MPCs. This tends to make fiscal stimulus less effective and is what we find empirically.

Stimulus payments have often been used as a response to large economic downturns. For example, both the 2001 economic recession and the 2008 financial crisis saw direct federal stimulus payments to households. There is extensive literature on households' responses to these tax rebates and stimulus payments. The existing studies exploit the differences in timing of the arrival of the payment to infer causal effects. Our results are generally comparable although it appears that during the 2020 stimulus, overall MPCs are smaller households spend much of their stimulus checks in a shorter period of time and more on food and non-durables than on durable consumption like furniture, electronics, or cars.

Using spending data from the Consumer Expenditure Survey Johnson, Parker and Souleles (2006) and Parker, Souleles, Johnson and McClelland (2013) look at the tax rebates granted in 2001 and the economic stimulus payments in 2008. For the 2001 rebates, Johnson, Parker and Souleles (2006) find that households spend $20-40 \%$ on non-durable goods during the quarter in which they received the rebate - the effect also carried over to the next quarter. Parker, Souleles, Johnson and McClelland (2013) focus on the stimulus payment in 2008 and finds large and positive effects on spending in the same range. The authors document positive effects on spending in both non-durable and durable goods. Broda and Parker (2014) use high-frequency scanner data and find large positive effects on spending. In Section 6.1, we discuss some of the differences between our estimates and the previous literature that analyze previous stimulus programs.

Besides looking at aggregate effects, studies have also found heterogeneous effects across agents. Agarwal, Liu and Souleles (2007) work with credit card accounts and found that customers initially saved the tax rebates in 2001, but then increased spending later on. In their setting, customers with low liquidity were most responsive. Misra and Surico (2014) use a quantile framework to look at the 2001 tax rebates and the 2008 economic stimulus payments on the distribution of changes in consumption.

Kaplan and Violante (2014) focus on the 2001 tax rebates and use a structural model to document that responsiveness to rebates is driven by liquid wealth. Households with sizable quantities of illiquid assets but low liquidity are an important driver of the magnitude of the response. To our knowledge, our study is the first to look at stimulus payments using high- 
frequency transaction data, as such data did not exist in 2008. ${ }^{1}$ The use of transaction data allows us to explore very-short term responses across categories, minimize measurement error, and explore individual daily heterogeneity in income declines and available cash on hand.

In this paper, we focus on a very different type of recession than previous stimulus programs: one stemming from an infectious disease outbreak that caused widespread business and government shutdowns. In comparison to the 2001 and 2008 economic downturns, the downturn due to COVID-19 was inflicted on households at a much faster pace, causing large job losses much more quickly. In addition, the pandemic has the potential to have large initial effects on income and liquidity, but potentially comparatively less on future income and wealth.

While previous studies have pointed out that stimulus payments have positive but heterogeneous effects on spending, analyzing the 2020 stimulus program will help us learn more about effects on spending and households in different economic circumstances. In particular, this crisis was so fast moving that households had little ability to anticipate income declines and increase precautionary savings. Additionally, many sectors of the economy were shut down due to state orders, which can impact the effectiveness of fiscal stimulus. Some policymakers argued that many businesses shutdowns makes conventional fiscal stimulus obsolete. ${ }^{2}$

Our results are also important for the ongoing discussion of Representative Agent Neo-Keynesian (RANK) and Heterogeneous Agent Neo-Keynesian (HANK) models. RANK and HANK models often offer starkly different predictions, and the observed MPC heterogeneity highlights the importance of the HANK framework. In a recent attempt to study pandemics in a HANK framework, Kaplan, Moll and Violante (2020) show that for income declines up to 70\%, consumption declines by $10 \%$, and GDP per capita by $6 \%$ in a lockdown scenario coupled with economic policy responses. In another recent working paper, Bayer, Born, Luetticke and Müller (2020) calibrate a HANK model to study the impact of the quarantine shock on the US economy in the case of a successful suppression of the pandemic. In their model, the stimulus payment help stabilize consumption and results in an output decline less than 3.5\%. Additionally, Hagedorn, Manovskii and Mitman

\footnotetext{
${ }^{1} \mathrm{~A}$ small number of papers use transaction-level data to look at spending responses to other income, such as Gelman, Kariv, Shapiro, Silverman and Tadelis (2014), Baker (2018), Kuchler and Pagel (2020), Olafsson and Pagel (2018), Baker and Yannelis (2017), Baugh, Ben-David, Park and Parker (2018), and Kueng (2018). Broda and Parker (2014) explore some higher frequency weekly responses using Nielsen Homescan data.

${ }^{2}$ For example, Joshua Rauh the former chair of the President's Council of Economic advisers noted that: " $a$ contraction cannot be addressed via conventional fiscal stimulus since no increase in consumer demand will cause restaurants closed on government orders to re-open."
} 
(2019) study multipliers in a HANK framework, whose size can depend on market completeness and the targeting of the stimulus.

This paper also joins a fast-growing literature on the effects of the COVID-19 pandemic on the economy, and policy responses. Several papers develop macroeconomic frameworks of epidemics, e.g. Jones, Philippon and Venkateswaran (2020), Barro, Ursua and Weng (2020), Eichenbaum, Rebelo and Trabandt (2020), and Kaplan, Moll and Violante (2020). Gormsen and Koijen (2020) use stock prices and dividend futures to back out growth expectations. Coibion, Gorodnichenko and Weber (2020) study short-term employment effects and Baker, Bloom, Davis and Terry (2020a) analyze risk expectations. Granja, Makridis, Yannelis and Zwick (2020) study the targeting and impact of the Paycheck Protection Program (PPP) on employment. Barrios and Hochberg (2020) and Allcott, Boxell, Conway, Gentzkow, Thaler and Yang (2020) show that political affiliations impact the social distancing response to the pandemic, and Coven and Gupta (2020) study disparities in COVID-19 infections and responses.

Our related paper, Baker, Farrokhnia, Meyer, Pagel and Yannelis (2020b), studies household consumption during this onset of the pandemic in the United States using the same data source. Carvalho, Garcia, Hansen, Ortiz, Rodrigo, Mora and Ruiz (2020), Andersen, Hansen, Johannesen and Sheridan (2020), Bounie, Camara and Galbraith (2020), Chen, Qian and Wen (2020) perform similar analyses as the one in this paper using transaction-level data from the Spain, Denmark, France, and China. Dunn, Hood and Driessen (2020) uses transaction-level data from the US provided by merchants rather than individual-level data and find similar results to Baker, Farrokhnia, Meyer, Pagel and Yannelis (2020b). We join this emerging and rapidly-growing literature by providing early evidence on how households responded to the crisis and the impact of federal stimulus policy. The results suggesting that MPCs are much higher for low liquidity households are important in designing future rounds of stimulus, if the effects of the epidemic persist over the next months.

The remainder of this paper is organized as follows. Section 2 provides background information regarding the 2020 stimulus and our empirical strategy. Section 3 describes the main transaction data used in the paper. Section 4 presents the main results and Section 5 discusses heterogeneity by income, income drops, and liquidity. Section 6 compares around findings to similar stimulus programs, discusses results for mortgage, credit card and other payments and presents a simple 
model to explain how fiscal multiplier effects may be differ from prior stimulus programs. Section 7 concludes and suggests directions for future research.

\section{Institutional Background and Empirical Strategy}

\subsection{Household Stimulus}

COVID-19, the novel coronavirus first identified in Wuhan, China spread worldwide in February 2020. The new virus had a mortality rate which, by some estimates, is ten times higher than the seasonal flu and has at least twice the rate of infection. The first case in the United States was identified in late January in Washington state and slowly spread within the country throughout February. By mid-March, the virus was spreading rapidly, with significant clusters in the greater the New York, San Francisco, and Seattle areas. Federal and many state governments responded to the COVID-19 pandemic in a number of ways: by issuing travel restrictions, shelter-in-place orders, and closures of all non-essential businesses.

Subsequently, the federal government soon passed legislation aimed to ameliorating economic damage stemming from the spreading virus and shelter-in-place policies. The CARES Act was passed on March 25, 2020 as a response to the economic damage of the new virus. The Act cost approximately $\$ 2$ trillion and included a number of provisions for households and businesses, including direct crash transfers to the vast majority of American households that are the focus of this study. These one-time payments consist of $\$ 1,200$ per adult and an additional $\$ 500$ per child under the age of 17. For an overview of amounts by household, see Appendix Table A.1. These amounts are substantially larger than the 2001 and 2008 stimulus programs. In 2020, a married couple with two children would thus earn $\$ 3,400$, a significant amount, particularly for liquidityconstrained households.

The vast majority of American households qualified for these payments. All independent adults who have a social security number, filed their tax returns, and earn below certain income thresholds qualify for the direct payments. Payments begin phasing out at $\$ 75,000$ per individual, $\$ 112,500$ for heads of households (single parents with children), and \$150,000 for married couples. The phase-out was completed and no payments were made to individuals earning more than $\$ 99,000$ 
or married couples earning more than $\$ 198,000$. $^{3}$

Payments are made by direct deposit whenever available, or by paper check when direct deposit information was unavailable. Funds are disbursed by the IRS, and the first payments by direct deposit were made on April 9th. The IRS expected that direct deposits would largely be completed by April 15th. In practice, the timing varied across banks and financial institutions, with some making payments available earlier than others, and direct deposits being spread out across more than one week. Amounts and accounts for direct deposits were determined using 2019 tax returns, or 2018 tax returns if the former were unavailable.

For individuals without direct deposit information, paper checks were scheduled to be mailed starting on April 24th. Approximately eight in ten taxpayers use direct deposit to receive their tax refunds, though given changes in banking information or addresses, many individuals were unable to receive their payments through direct deposit even when they had received prior tax refunds via direct deposit. In the case of paper checks, the order of payments across households is not random. The IRS directed to send individuals with the lowest adjusted gross income checks first in late April, and additional paper checks will be sent throughout May. Appendix A provides further details regarding the timing of payments and the stimulus.

\subsection{Empirical Strategy}

Our empirical strategy exploits our high-frequency data and the timing of stimulus payments to capture spending responses. We first show estimates of $\beta_{i}$ from the following specification:

$$
c_{i t}=\alpha_{i}+\alpha_{t}+\sum_{t=-7}^{23} \beta_{i} \mathbb{1}[t=i]_{i t}+\varepsilon_{i t}
$$

$c_{i t}$ denotes spending by individual $i$ aggregated to the daily level $t . \alpha_{i}$ are individual fixed effects, while $\alpha_{t}$ are date fixed effects. Individual fixed effects $\alpha_{i}$ absorb time invariant userspecific factors, such as some individuals having greater average income or wealth. The date fixed effects $\alpha_{t}$ absorb time-varying shocks that affect all users, such as the overall state of the economy and economic sentiment. In some specifications, we interact individual fixed effects with

\footnotetext{
${ }^{3}$ Due to data limitations, in identifying stimulus payments, we are unable to identify these partial payments from these higher-income households. However, these individuals are a very small fraction of total households, both overall and particularly in our sample which is skewed towards lower income households.
} 
day of the week or day of the month fixed effects to capture consistent time-varying spending patterns over the week and month. For example, some individuals may spend more on weekends, or on their paydays. $\mathbb{1}[t=i]$ is an indicator of a time period $i$ days after receipt of the stimulus payment. We run regressions at a daily level to examine more precisely the high frequency changes in behavior brought about by the receipts of the stimulus payments. Standard errors are clustered at the individual level. The coefficient $\beta_{i}$ captures the excess spending on a given day before and after stimulus payments are made. In our graphs, the solid lines show point estimates of $\beta_{i}$, while the dashed lines show 95\% confidence intervals.

We identify daily MPCs using the following specification:

$$
c_{i t}=\alpha_{i}+\alpha_{t}+\sum_{t=-7}^{23} \gamma_{i} P_{i t} \times \mathbb{1}[t=i]_{i t}+\varepsilon_{i t}
$$

where $P_{i t}$ are stimulus payments for individual $i$ at time $t$. To identify cumulative MPCs since the first payment, we scale indicators of a time period being after a stimulus payment by the amount of the payment over the number of days since the payment. That is, our estimate of a cumulative MPC $\zeta$ comes from the following specification:

$$
c_{i t}=\alpha_{i}+\alpha_{t}+\zeta\left(\frac{\text { Post }_{i t} \times P_{i}}{D_{i t}}\right)+\varepsilon_{i t}
$$

where $P_{i}$ is the stimulus payment an individual $i$ is paid, and $D_{i t}$ is the total number of days over which we estimate the MPC and Post ${ }_{i t}$ is an indicator of the time period $t$ being after individual $i$ receives a stimulus payment. The coefficient $\zeta$ thus captures the aggregate effect of of the stimulus in the time period in question, by scaling the average effect per day by the number of days since receipt. The resulting coefficients can be interpreted as the fraction of stimulus money spent during that period: a coefficient of 0.05 corresponds to the user spending $5 \%$ of their stimulus check during their observed post-stimulus period. ${ }^{4}$

\footnotetext{
${ }^{4}$ As an example to illustrate this, imagine that a $\$ 1$ transfer leads to $\$ 1$ dollar of additional spending in the day immediately after receipt. Thus if we estimated the effect over one day, we would scale by 1 and $\zeta=1$. If we estimate the effect over 10 days, the average effect each day is 0.1 , which would be the coefficient on a regression of $P_{o s t} \times P_{i}$ and we scale by 10 so again $\zeta=1$. If we estimate the effect over 100 days, the average effect per day is 0.01 , again we would scale by 100 and so on.
} 


\section{Data}

\subsection{Transaction Data}

In this paper, we utilize de-identified transaction-level data from SaverLife, a non-profit helping working families develop long-term savings habits and meet financial goals. As with a number of other personal financial apps, SaverLife allows users to link their main bank accounts to their service. Users can link their checking, savings, as well as their credit card accounts. SaverLife offers users the ability to aggregate financial data and observe trends and statistics about their own spending. In addition, SaverLife gives matching rewards and lotteries when customers with linked accounts achieve pre-specified savings goals on a weekly or monthly basis.

Figure 1 shows two screenshots of the online interface in the app. The first is a screenshot of the linked main account while the second is a screenshot of the savings and financial advice resources that the website provides. This data is described in more detail in Baker, Farrokhnia, Meyer, Pagel and Yannelis (2020b).

Overall, we have been granted access to de-identified bank account transactions and balances data from August 2016 to May 2020. We observe 44,660 users in total who live across the United States. In addition, for a large number of users, we are able to link financial transactions to selfreported demographic and spatial information such as age, education, ZIP code, family size, and the number of children they have.

We also observe a category that classifies each transaction. Spending transactions are categorized into a large number of categories and subcategories. For the purposes of this paper, we mostly analyze and report spending responses into the following aggregated categories: Food, Household goods and personal care, Durables like auto-related spending, furniture, and electronics, Nondurables and services, and Payments including check spending, loans, mortgages, and rent. Across all specifications, we exclude transactions that represent transfers between accounts like transfers to savings or investment accounts or credit card payments.

Looking only at the sample of users who have updated their accounts reliably up until April 2020, we have complete data for 6,033 users to analyze in this paper. We require these users to have several transactions per month in 2020 and have transacted at least $\$ 1,000$ in total during these three months of the year. Requiring regular prior account usage is frequently used as a 
completeness-of-record check when using bank-account data (Kuchler and Pagel, 2019).

In Table 1 we report descriptive statistics for users' spending in a number of selected categories as well as their incomes at the monthly level. We note that income is relatively low for many SaverLife users, with an average level of income being approximately $\$ 25,000$ per year. In addition, we show the distribution of balances across users' accounts during the week before most stimulus checks arrived. Consistent with the low levels of income, we see that most users maintain a fairly low balance in their financial account, with the median balance being only $\$ 141.02$. Finally, we report the distribution of some demographic characteristics for users.

We identify stimulus payments using payment amounts stipulated by the CARES Act, identifying all payments at the specific amounts paid after April 9th in the categories 'Refund', 'Deposit', and 'Credit.' Figure 2 shows the identified number of payments of this type, relaxing the time restrictions in 2019 and 2020. While there are a small number of payments in these categories at the exact stimulus amounts prior to the beginning of payments, there is a clear massive increase in frequency after April 9th. This suggests that there are relatively few false positives, and that the observed payments are due to the stimulus program and no other payments of the same amount.

As of May 16th, approximately 53\% of users have received a stimulus payment into their linked account. The remainder of the sample may be still waiting for a stimulus check or may be ineligible for one. Some banks and credit unions had issues processing stimulus deposits and these deposits were still pending for a number of Americans. In addition, users may not have had direct deposit information on file with the IRS and would then need to wait for a check to be mailed. Finally, users may be ineligible for stimulus checks due to their status as a dependent, because they did not file their taxes in previous years, or because they made more than the eligible income thresholds for receipt. Of those who receive payments two-thirds received them by April 15, with $40 \%$ of all payments occurring on April 15. $92 \%$ of those who received payments in our sample did so in April.

While most American households were due to receive a stimulus check, the amount varied according to the number of tax filers and numbers of children. Each qualifying adult could receive up to $\$ 1,200$ and an additional $\$ 500$ for each dependent child. Table A.1 gives an accounting of amounts due to a range of household types. While we cannot observe the exact household composition for each user, we are able to observe a self-reported measure of household size. Our 
measure matches up reasonably well with the received stimulus payments.

Appendix A provides further details regarding payments in our sample. Payments line up closely with self-reported household size. Because of our strategy for picking out stimulus checks, being within the 'phase-out' region of income would mean that we would falsely classify an individual as having not received a stimulus check, since his or her check would be for a noneven number. This would likely attenuate our empirical estimates slightly. We conduct a placebo exercise in the appendix, and look at spending around April for households that do not receive a check. We do not see any sharp breaks in spending beyond day of the week effects, suggesting that these effects are small if present.

\section{Effects of Stimulus Payments}

Looking at the raw levels of spending for users receiving stimulus payments, Figure 3 shows mean daily spending before and after the receipt of a stimulus payment without any other controls or comparison group. In this figure, we only show spending data for users who receive a stimulus check in our sample period. Prior to receiving a check, the typical individual in the sample is spending under $\$ 100$ a day. There is a sharp and immediate increase in spending following the receipt of a stimulus deposit. Mean daily spending rises on the day of receipt to approximately $\$ 150$ and continues to increase, to over $\$ 200$, for the two days after the receipt of the stimulus payment.

Observed spending declines substantially in the third and fourth days, though most of this is driven by the fact that a majority of 'treated' users in our sample received the stimulus check on Wednesday, April 15th and spending tends to decline on weekends. After the weekend period, observed spending rises to $\$ 250$ before beginning to decline. ${ }^{5}$

While Figure 3 provides some evidence that spending was affected by the stimulus payments, we want to directly compare users receiving stimulus payments to those that did not receive one at that time. Figure 4 shows estimates of $\beta_{i}$ from the equation: $c_{i t}=\alpha_{i}+\alpha_{t}+\sum_{t=-7}^{23} \beta_{i} \mathbb{1}[t=i]_{i t}+\varepsilon_{i t}$. 'Time to Payment' is equal to zero for a user on the day of receiving the stimulus check. Here,

\footnotetext{
${ }^{5}$ Observed spending tends to decline dramatically on weekends throughout our sample. This is likely driven by two factors. The first is that actual transactions and spending declines during these days. The second is that transactions that occurred during the weekend may process only on the Monday that follows. We are unable to distinguish between these cases using our data.
} 
we see that users who receive stimulus checks tend to not behave differently than those that do not in the days before they receive the checks. Upon receiving the stimulus check, users dramatically increase spending relative to users who do not receive the checks.

Similar to what we saw looking at the raw spending data, users show large increases in spending in the first days following the stimulus check receipt and keep spending significantly more than those who have not received checks for the entirety of the post-check period that we observe. The relative difference in spending declines during weekends, mostly driven by the fact that observed levels of spending tends to be depressed during these days for reasons described above.

In Figure 5, we break down users' spending responses by categories of spending. We map our categories to roughly correspond to those reported in Parker, Souleles, Johnson and McClelland (2013) from the CEX: food, household goods and personal care, durables like auto-related spending, furniture, and electronics, non-durables and services, and payments including check spending, loans, mortgages, and rent.

Across all categories, we find statistically significant increases in spending following the receipt of a stimulus check. These responses are widely distributed across categories, with cumulative spending on food, household, non-durables, and payments each increasing by approximately $\$ 50$ $\$ 75$ in the three days following receipt of a check. Durables spending sees a significant increase, but it is much smaller in economic terms with only a $\$ 20$ relative increase in spending during the first three days.

Table 2 presents similar information, presenting coefficients from the regression $c_{i t}=\alpha_{i}+$ $\alpha_{t}+\sum_{t=-7}^{23} \beta_{i} \mathbb{1}[t=i]_{i t}$ Stimulus $_{i}+\varepsilon_{i t}$. That is, we examine the excess spending among users who received stimulus payments on each day following the receipt of their stimulus checks, scaled by the size of their payment. A value of 0.03 can be interpreted as the user spending, on day $t, 3 \%$ of their stimulus check more than a user who did not receive a check.

Columns 1-3 test how total user spending responds with three different sets of fixed effects. Column 1 presents results using individual and day of the month fixed effects. Column 2 also includes individual-by-day-of-month fixed effects, and Column 3 includes individual, calendar date, and individual-by-day-of-week fixed effects. We find similar effects across all specifications, with spending among those who received a stimulus check tending to increase substantially in the first week after stimulus receipt. 
Spending on days during this period are economically and statistically significantly higher for those receiving stimulus checks and there are no days with significant reversals - days with stimulus check recipients having lower spending than those who did not. Overall, for each dollar of stimulus received, households spent approximately \$0.2-0.3 more in the month following the stimulus.

The remainder of the columns in Table 2 decompose the effect that we see in overall spending according to the category of spending. We split spending into 5 categories: food, non-durables, household goods and services, durables, and other payments. We find significant increases in spending in all of these categories, with the largest increases coming from spending on food, nondurables, and household goods and services. We find muted effects of the stimulus payments on durables spending. In previous recessions, noted by Parker, Souleles, Johnson and McClelland (2013), spending on durables (mainly auto-related spending), was a large component of the household response to stimulus checks. At least in the short-term, we find significantly different results, with durables spending contributing negligibly to the overall household response. We discuss some of these differences relative to past stimulus programs in Section 6.1

\section{Income Levels, Income Declines, and Liquidity}

The stimulus payments employed in the United States were sent to taxpayers with minimal regard for current income, wealth, and employment status. While there was an income threshold above which no stimulus would be received, this threshold was fairly high relative to average individual income and most Americans were therefore eligible for stimulus payments. During debates about the size and scope of the stimulus, a common question was whether Americans with higher incomes, unaffected jobs, and higher levels of wealth needed additional financial support. With data on both the income and bank balances of SaverLife users, we are able to test whether the consumption and spending responses differed markedly between users who belonged to these different groups.

In Figures 6-7, we show the cumulative estimated MPCs from regressions of spending on an indicator of a time period being after a stimulus payment is received. Each figure contains the results of multiple regressions, with users broken down into subsamples according to a number 
of financial characteristics that we can observe. That is, the graphs represent the sum of daily coefficients seen in a regression as in Table 2, by group. In these figures, we divide the samples of users by their level of income, the drop in income we observed over the course of 2020, and their levels of liquidity prior to the receipt of stimulus payments.

Figure 6 splits users by their average income in the six months prior to March 2020. We see clear evidence that users with lower levels of income tended to respond much more strongly to the receipt of a stimulus payment than those with higher levels of income. Users who had typically earned under $\$ 1,000$ per month saw an MPC approximately twice as large as users who typically earned $\$ 5,000$ a month or more.

We also examine whether a similar pattern can be seen among users who have had declines in income following the COVID outbreak. In Figure 8, for each user, we measure the change in income received in March 2020 relative to how much was received, on average, in January and February 2020. We split users into those who had a decline in monthly income of $50 \%$ or more, those who had declines in income of less than 50\%, and those who saw no decline in income (or had an increase). In general, we see that users who saw larger declines in income tended to have larger spending responses to the receipt of stimulus checks, though the differences are not as substantial as those in Figure 6.

Finally, we split our sample of users according to their accounts' balances at the beginning of April. We separate users into four groups: those with balances under $\$ 500$, those with balances between $\$ 500$ and $\$ 1,000$, those with balances between $\$ 1,000$ and $\$ 3,000$, and those with balances over $\$ 3,000$. Figure 7 displays results from these four regressions. We see dramatic differences across groups of users. Users with the highest balances in their bank accounts tend not to respond to the receipt of stimulus payments, while those who had under $\$ 500$ respond the most. The low balance group has an MPC out of the stimulus payment of about 0.4 in the first 9 days of receipt.

Table 3, Table 5, and Table 4 display some of these results in regression form. In general, we find that users with lower incomes, larger drops in income, and lower pre-stimulus balances tend to respond significantly more strongly than other users. Again, across all subsamples of our users based on financial characteristics, we see that low liquidity tends to be the strongest predictor of a high MPC and high liquidity tends to be the strongest predictor of low MPCs. This is true even among individuals who have high incomes but low levels of cash on hand. 


\section{The 2020 Stimulus and Previous Economic Stimulus Programs}

\subsection{Comparison to Previous Economic Stimulus Programs}

Johnson, Parker and Souleles (2006) and Parker, Souleles, Johnson and McClelland (2013) examine the response of households to economic stimulus programs during the previous two recessions (2001 and 2008). These programs were similar in nature to the stimulus program in 2020 but were smaller in magnitude. In 2001, individuals generally received $\$ 300$ rebates, with married couples generally eligible for $\$ 600$. In 2008 , couples could receive $\$ 1,200$ and $\$ 300$ for each dependent child. In the 2020 stimulus program, couples could receive $\$ 2,400$ and each dependent child would be eligible for $\$ 500$.

In these previous stimulus programs, households also tended to respond strongly to the receipt of their checks. For instance, in 2008, Parker, Souleles, Johnson and McClelland (2013) estimated that households spent approximately $12-30 \%$ of their stimulus payments on non-durables and services and a total of $50-90 \%$ of their checks on total additional spending (including durables) in the six months following receipt. In 2001, approximately 20-40\% of stimulus checks were spent on non-durables and services in the six months following receipt. In one paper examining the high-frequency responses (Broda and Parker, 2014), the authors are able to use Nielsen Homescan data to examine weekly spending responses to the 2008 stimulus payments. They find that a household's spending on covered goods increased by approximately ten percent in the week that it received a payment, with an MPC of approximately .5 by the month after stimulus check receipt. Spending remained elevated for approximately three months following stimulus payment receipt, although more than $70 \%$ of the excess spending is in the month that the check is received.

While they were not always able to examine the timing of all types of spending in more detail due to data limitations in previous recessions, we demonstrate that households respond extremely quickly to receiving stimulus checks. Rather than taking weeks or months to spend appreciable portions of their stimulus checks, we show that households react extremely rapidly, with household spending increasing by approximately one third of the stimulus check within the first 10 days. Given that previous stimulus programs saw sustained increases in spending lasting six months or more, we would expect that the long-run impact of the 2020 stimulus program would be much larger than the already sizable short-run effect that we have seen so far. 
Another notable difference from the stimulus program during the 2008 recession is the variation in magnitudes and spending responses across categories. We find smaller estimates of MPCs, which is driven by low durable spending. In non-durable categories, we find similar estimates relative to previous work. Previous research has found strong responses of durables spending to large tax rebates and stimulus programs, especially on automobiles (about $90 \%$ of the estimated impact on durables spending in the 2008 stimulus program was driven by auto spending). In contrast, despite a sizable response in non-durables and service spending, we see little immediate impact on durables. Even if we attribute the entirety of our observed response in the 'Payments' category to spending on durables, the magnitude is much smaller than the combined response in food and non-durables categories. Moreover, the payments category also includes rent and bill payments which compose a portion of the 'Payments' category increase.

This difference becomes even starker if we consider the fact that some prior literature has shown that larger payments often result in spending responses that skew more towards durables. Given the size of the 2020 stimulus checks, we might have expected large impacts on categories like automobile spending, electronics, appliances, and home furnishings. Instead it seems that individuals are catching up with rent and bill payments as well as engaging in spending on food, personal care, and non-durables.

In part, this discrepancy with past recessions may be driven by the fact that automobile use and spending is highly depressed, with many cities and states being under shelter-in-place orders and car use being restricted. Similarly, as these orders hinder home purchases, professional installment, and moves, spending on home furnishings and other related durables may be lower as well (the stimulative effects of home purchases on home durables are demonstrated in Benmelech, Guren and Melzer (2019)).

While increases in durables spending were limited in the 2020 stimulus setting, we find substantial increases in spending on food. This again stands in contrast to some of the effects seen in earlier stimulus programs. Again, it may reflect the unique economic setting in which the 2020 economic stimulus took place. While many outlets for consumer spending were closed by government order, restaurants remained open; we find that household spending on food delivery was one category in particular that increased following the receipt of a stimulus check.

Finally, across both 2001 and 2008, Parker, Souleles, Johnson and McClelland (2013) note that 
lower income households tend to respond more, and that households with either larger declines in net worth or households with lower levels of assets also tend to respond more strongly to stimulus checks. These results are largely consistent with the patterns we observe in 2020 . We find that households with low levels of income and lower levels of wealth tend to respond much more strongly. In addition, our measure of available liquidity from actual account balances arguably suffers from much less measurement error than the measures used in previous research on stimulus checks, giving additional confidence in our estimates.

\subsection{Payments}

In Figure 9 and Table 6, we report the impact of the stimulus check on financial payments. In particular, we examine the impact on total financial payments as well as payments on several subsets of financial payments such as credit card payments as well as rent and mortgage payments. Rent payments are not always able to be accurately identified due to the number of users who utilize checks or online transfer tools like Chase QuickPay, Zelle, or Venmo to pay their rent. Such payments will still be accurately captured by the 'Total Payments' category.

We find that financial payments surge substantially upon receipt of the 2020 stimulus payments. Marginal spending on total financial payments totals about one third of total MPC out of the stimulus payments.

\subsection{Modeling the Effectiveness of Fiscal Stimulus Payments}

We now present a simple model that outlines two reasons, consistent with our empirical findings, that the fiscal stimulus in 2020 may be less effective in actually stimulating the economy than the 2001 or 2008 payments. The basic reason for this lack of effectiveness is that sectors of the economy employing workers with the lowest levels of liquidity are shut down, leading to lower fiscal multipliers.

Suppose that we have three types of sectors and workers employed by those sectors. First, we have a sector that we call groceries and necessities. Here, we refer to large firms that sell groceries and basic household supplies that are both essential and non-durable (moderate depreciation). For instance, large supermarkets or stores such as Target, Walmart, and CVS. At the same time, the 
grocery and necessity sector is moderately labor intensive. This sector is not shut down in response to an epidemic.

In turn, we have a second sector, called restaurants and hospitality, that produces non-durable consumption which depreciates immediately and is more labor intensive than the first sector. Being less essential to households, the second sector is shut down in response to the crisis.

Finally, we have a third sector of the economy. This sector is broader, and encompasses durables production as well as many white-collar services like banking and tech. This sector can avoid being locked down through employing safety measures in production or by working remotely. This sector pays higher wages than in sectors 1 and 2. Consequently, the corporations in sectors 1 and 2 are owned by the workers in sector 3 . We assume that workers in sector 1 and 2 borrow (for example, rent, mortgages, or financial lending) from workers in sector 3.

The effectiveness of fiscal stimulus rests on the idea that stimulus checks induce extra spending by recipients. For example, workers in sector 3 spend in sector 2 and generate income for workers in that sector that is then spent again. Thus, if the MPC out of a stimulus payment is 0.8 , then out of a $\$ 100$ payment, $\$ 80$ is consumed, generating $\$ 80$ of income for another worker. That worker then again consumes $\$ 64$ which generates income for another worker, and so on.

In this framework, there are two reasons why fiscal stimulus is less effective in this environment relative to the 2001 and 2008 recessions. First, in a lockdown induced by an epidemic, neither group of workers can spend in sector 2. At the same time, workers in sector 2 are the poorest and have the highest MPCs. Second, workers in sectors 1 and 2 (that are poorer) use the stimulus payment to pay down debt held by sector 3 workers. Therefore, the excess spending from the stimulus flows to workers that have a lower MPC.

More formally, we have a three-period model inspired by Guerrieri, Lorenzoni, Straub and Werning (2020) and consider an economy with three sectors. All sector $s$ agents' preferences are represented by the utility function:

$$
\sum_{t=0}^{3} \beta^{t} U\left(c_{t}^{s}\right)
$$

where $c_{t}^{s}$ is consumption and $U(c)=c^{1-\sigma} /(1-\sigma)$ is a standard power utility function. Each agent is endowed with $\bar{n}_{t}^{s}>0$ units of labor which are supplied inelastically but they can only 
work in their own sector. Competitive firms in each sector $s$ produce the final good from labor using the linear technology:

$$
Y_{t}^{s}=\bar{n}_{t}^{s}
$$

Each agent maximizes utility subject to:

$$
c_{t}^{s}+a_{t}^{s} \leq w_{t}^{s} \bar{n}_{t}^{s}+\left(1+r_{t-1}\right) a_{t-1}^{s} .
$$

As the initial condition, we assume that agents in sectors 1 and 2 borrow from agents in sector 3 , such that $a_{1}^{1}<0, a_{1}^{2}<0$, and $a_{1}^{1}+a_{1}^{2}=-a_{1}^{3}$. Given the economy is frictionless, agents choose their consumption to satisfy their Euler equation:

$$
U^{\prime}\left(c_{t}^{s}\right)=\beta\left(1+r_{t}\right) U^{\prime}\left(c_{t+1}^{s}\right)
$$

Because preferences are homothetic, we can think of all agents in each sector as just being represented by one agent. In turn, each agent can consume consumption goods from any sector, denoted by $c_{t}^{s s}$. The consumption composite, $c_{t}^{s}$, over the three sectors' consumption goods equals $f_{c}\left(c_{t}^{s 1}, c_{t}^{s 2}, c_{t}^{s 3}\right)$ and relative goods prices meeting the composite constraint $p_{t} c_{t}^{s}=p_{t}^{1} c_{t}^{s 1}+p_{t}^{2} c_{t}^{s 2}+$ $p_{t}^{3} c_{t}^{s 3}$ adjust to ensure full employment in each sector. Additionally, we assume that $\left.\frac{\partial f_{c}}{c_{t}^{s 1}}\right|_{c_{t}^{s 1} \rightarrow 0}=$ $\infty$ whereas $\left.\frac{\partial f_{c}}{c_{t}^{s^{2}}}\right|_{c_{t}^{s 2} \rightarrow 0}$ and $\left.\frac{\partial f_{c}}{c_{t}^{s 2}}\right|_{c_{t}^{s 2} \rightarrow 0}$ approach finite numbers, which implies that consumption purchased in sector 1 is necessary, whereas it is not necessary when it comes from sectors 2 and 3 . Finally, the goods market clearing condition has to hold in each period:

$$
c_{t}^{s}=\bar{n}_{t}^{s}
$$

Suppose the central bank implements a fixed rate $1+r_{0}=1 / \beta$ and the economy starts from a state in which each agent consumes his or her labor income in composite consumption $c_{1}^{s}=w_{1}^{s} \bar{n}_{1}^{s}$ and does not accumulate or decumlate their debt or savings. In turn, in period 2, an unexpected shock hits that restricts agents working in sector 2 in periods 2 and 3, i.e., $w_{2}^{2}=w_{3}^{2}=0$, and the government promises a stimulus payment $S$ in period 3. Then agents in sector 2 allocate consumption in periods 2 and all the following periods according to their Euler equation and budget constraints. 


$$
U^{\prime}\left(c_{2}^{2}\right)=U^{\prime}\left(c_{3}^{2}\right), c_{2}^{2}+a_{2}^{2} \leq 1 / \beta a_{1}^{2} \text {, and } c_{3}^{2}=S+1 / \beta a_{2}^{2}
$$

In turn, we obtain:

$$
c_{2}^{2}=c_{3}^{2}=\frac{S+1 / \beta^{2} a_{1}^{2}}{1+1 / \beta} \text { and } a_{2}^{2}=1 / \beta a_{1}^{2}-\frac{S+1 / \beta^{2} a_{1}^{2}}{1+1 / \beta} .
$$

Agents in sector 1 allocate consumption in periods 2 and 3 according to their Euler equation and budget constraints in the same manner and we obtain:

$$
\begin{gathered}
c_{2}^{1}=c_{3}^{2}=\frac{S+w_{3}^{1} \bar{n}_{3}^{1}+1 / \beta\left(w_{2}^{1} \bar{n}_{2}^{1}+1 / \beta a_{1}^{1}\right)}{1+1 / \beta} \text { and } \\
a_{2}^{1}=w_{2}^{1} \bar{n}_{2}^{1}+1 / \beta a_{1}^{1}-\frac{S+w_{3}^{1} \bar{n}_{3}^{1}+1 / \beta\left(w_{2}^{1} \bar{n}_{2}^{1}+1 / \beta a_{1}^{1}\right)}{1+1 / \beta} .
\end{gathered}
$$

Consumption for agents in sector 3 follows the above straightforwardly.

Proposition 1. The MPC out of income (or fiscal stimulus payments) is larger for agents in sector 2 than for agents in sectors 1 or 3.

Proof. Compare MPCs, i.e., how much out of income (or fiscal stimulus payments) are consumed:

$$
\begin{gathered}
\frac{\partial c_{2}^{2}}{\partial S}=\frac{\partial c_{3}^{2}}{\partial S}=\frac{\partial\left(\frac{S+1 / \beta^{2} a_{1}^{2}}{(1+1 / \beta)}\right)}{\partial S}=\frac{1}{1+1 / \beta}>\frac{\partial c_{2}^{1}}{\partial\left(S+w_{2}^{1} \bar{n}_{2}^{1}+w_{3}^{1} \bar{n}_{3}^{1}\right)} \\
\operatorname{as} \frac{\partial\left(\frac{S+w_{2}^{1} \bar{n}_{2}^{1}+w_{3}^{1} \bar{n}_{3}^{1}+(1 / \beta-1) w_{2}^{1} \bar{n}_{2}^{1}+1 / \beta^{2} a_{1}^{1}}{1+1 / \beta}\right)}{\partial\left(S+w_{2}^{1} \bar{n}_{2}^{1}+w_{3}^{1} \bar{n}_{3}^{1}\right)}=\frac{1}{1+1 / \beta}+\underbrace{\frac{\partial\left(\frac{(1 / \beta-1)}{1+1 / \beta} w_{2}^{1} \bar{n}_{2}^{1}\right)}{\partial\left(S+w_{2}^{1} \bar{n}_{2}^{1}+w_{3}^{1} \bar{n}_{3}^{1}\right)}}_{<0} \text { and } \frac{(1 / \beta-1)}{1+1 / \beta}<0 .
\end{gathered}
$$

This argument extends straightforwardly to the comparison of agents in sectors 2 and 3.

Proposition 2. The marginal propensity to repay debt out of income (or fiscal stimulus payments) is larger for agents in sector 2 than for agents in sector 1 .

Proof. Compare the propensity to repay mortgages, i.e., how much out of income (or fiscal stimulus payments) are used to repay debt:

$$
\frac{\partial\left(-a_{2}^{2}\right)}{\partial S}=\frac{\partial\left(-1 / \beta a_{1}^{2}+\frac{S+1 / \beta^{2} a_{1}^{2}}{(1+1 / \beta)}\right)}{\partial S}=\frac{1}{1+1 / \beta}>\frac{\partial\left(-a_{2}^{2}\right)}{\partial\left(S+w_{2}^{1} \bar{n}_{2}^{1}+w_{3}^{1} \bar{n}_{3}^{1}\right)}
$$




$$
\text { as } \frac{\partial\left(-w_{2}^{1} \bar{n}_{2}^{1}-1 / \beta a_{1}^{1}+\frac{S+w_{2}^{1} \bar{n}_{2}^{1}+w_{3}^{1} \bar{n}_{3}^{1}+(1 / \beta-1) w_{2}^{1} \bar{n}_{2}^{1}}{1+1 / \beta}\right)}{\partial\left(S+w_{2}^{1} \bar{n}_{2}^{1}+w_{3}^{1} \bar{n}_{3}^{1}\right)}=\frac{1}{1+1 / \beta}+\underbrace{\frac{\partial\left(-w_{2}^{1} \bar{n}_{2}^{1}+\frac{(1 / \beta-1)}{1+1 / \beta} w_{2}^{1} \bar{n}_{2}^{1}\right)}{\partial\left(S+w_{2}^{1} \bar{n}_{2}^{1}+w_{3}^{1} \bar{n}_{3}^{1}\right)}}_{<0} \text {. }
$$

If we now compare this economy's to one in which sector 2 would not shut down, there are three differences that each diminish the amount of consumption induced by the stimulus payment $S$. First, agents in all sectors cannot consume in sector 2, thereby foregoing increases in employment and income in that sector. Secondly, sector 2 agents are the poorest agents with the highest MPC out of their income, so declines in their income disproportionately decrease the fiscal multiplier. Finally, agents in sector 2 choose to accumulate more debt in period 2 planning to repay it with their stimulus payment. In turn, the stimulus payment goes to agents in sector 3 that have lower MPCs out of the stimulus payment.

In summary, in this economy, workers in sectors 1 and 2 will spend their stimulus payment on mortgages and loan repayments as well as non-durable necessary consumption (sector 1). This tends to make fiscal stimulus less effective.

\section{Conclusion}

This paper studies the impact of the 2020 CARES Act stimulus payments on household spending using detailed high-frequency transaction data from SaverLife, a non-profit helping working families develop long-term savings habits and meet financial goals. We utilize this dataset to explore heterogeneity of MPCs in response to the stimulus payments, an important parameter both in determining multipliers and in testing between representative and heterogeneous agent models. We hope that our results inform the ongoing debate about appropriate policy measures and next steps given the unprecedented situation we are facing.

We find large consumption responses to fiscal stimulus payments and significant heterogeneity across individuals. Income levels, income declines, and liquidity all play important roles in determining MPCs. In 2020 stimulus, liquidity is the strongest predictor of MPC heterogeneity. We find substantial responses for households with low levels of liquidity and no response to stimulus payments for households with high levels of account balances or cash on hand. The results will 
potentially be important for policy-makers in terms of designing future rounds of stimulus if the 2020 crisis persists. Our results suggest that the effects of stimulus are much larger when targeted to households with low levels of liquidity.

While this paper shows that liquidity is an important determinant of MPC heterogeneity in response to stimulus payments and that targeted payments can be more effective at increasing consumption which imply larger multipliers, there remains important future analyses to be conducted. In particular, more work should be done to study how targeting can be designed to have large impacts on consumption, without significant behavioral effects. Just as unemployment benefits may increase unemployment durations (Meyer, 1990), policies targeting stimulus payments towards households with low levels of liquidity could discourage liquid savings. 


\section{References}

Agarwal, Sumit, Chunlin Liu, and Nicholas S Souleles, "The Reaction of Consumer Spending and Debt to Tax Rebates-Evidence from Consumer Credit Data,' Journal of Political Economy, $\operatorname{dec} 2007,115$ (6), 986-1019.

Allcott, Hunt, Levi Boxell, Jacob Conway, Matthew Gentzkow, Michael Thaler, and David Y Yang, "Polarization and Public Health: Partisan Differences in Social Distancing During the Coronavirus Pandemic," NBER Working Paper, 2020.

Andersen, Asger Lau, Emil Toft Hansen, Niels Johannesen, and Adam Sheridan, “Consumer Reponses to the COVID-19 Crisis: Evidence from Bank Account Transaction Data," Technical Report, Working Paper 2020.

Baker, Scott R, "Debt and the Response to Household Income Shocks: Validation and Application of Linked Financial Account Data," Journal of Political Economy, 2018, 126 (4), 1504-1557.

Baker, Scott R. and Constantine Yannelis, "Income Changes and Consumption: Evidence from the 2013 Federal Government Shutdown," Review of Economic Dynamics, 2017, 23, 99-124.

Baker, Scott R, Nicholas Bloom, Steven J Davis, and Stephen J Terry, "Covid-Induced Economic Uncertainty," National Bureau of Economic Research Working Paper, 2020.

_, RA Farrokhnia, Steffen Meyer, Michaela Pagel, and Constantine Yannelis, "How Does Household Spending Respond to an Epidemic? Consumption During the 2020 COVID-19 Pandemic," National Bureau of Economic Research Working Paper, 2020.

Barrios, John and Yael Hochberg, "Risk Perception Through the Lens Of Politics in the Time of the COVID-19 Pandemic," Working Paper, 2020.

Barro, Robert J, José F Ursua, and Joanna Weng, "The Coronavirus and the Great Influenza Epidemic," Working Paper, 2020.

Baugh, Brian, Itzhak Ben-David, Hoonsuk Park, and Jonathan A Parker, "Asymmetric Consumption Response of Households to Positive and Negative Anticipated Cash Flows," Technical Report, National Bureau of Economic Research 2018.

Bayer, Christian, Benjamin Born, Ralph Luetticke, and Gernot J. Müller, "The Coronavirus Stimulus Package: How Large is the Transfer Multiplier?," Working Paper, 2020. 
Benmelech, Efraim, Adam Guren, and Brian Melzer, "Making the House a Home: The Stimulative Effects of Home Purchases on Consumption and Investment," Working Paper, 2019.

Bounie, David, Youssouf Camara, and John W Galbraith, “Consumers' Mobility, Expenditure and Online-Offline Substitution Response to COVID-19: Evidence from French Transaction Data," Available at SSRN 3588373, 2020.

Broda, C and J Parker, “The Economic Stimulus Payments of 2008 and the Aggregate Demand for Consumption," Journal of Monetary Economics, 2014.

Carvalho, Vasco M., Juan R. Garcia, Stephen Hansen, Alvaro Ortiz, Tomasa Rodrigo, Jose V. Rodriguez Mora, and Jose Ruiz, "Tracking the COVID-19 Crisis with High-Resolution Transaction Data," Technical Report, Working Paper 2020.

Chen, Haiqiang, Wenlan Qian, and Qiang Wen, "The Impact of the COVID-19 Pandemic on Consumption: Learning from High Frequency Transaction Data," Available at SSRN 3568574, 2020 .

Coibion, Olivier, Yuriy Gorodnichenko, and Michael Weber, "Labor Markets During the COVID-19 Crisis: A Preliminary View," Fama-Miller Working Paper, 2020.

Coven, Joshua and Arpit Gupta, "Disparities in Mobility Responses to COVID-19," Technical Report 2020.

Dunn, Abe, Kyle Hood, and Alexander Driessen, "Measuring the Effects of the COVID-19 Pandemic on Consumer Spending Using Card Transaction Data," BEA Working Paper Series WP2020-5, 2020.

Eichenbaum, Martin S, Sergio Rebelo, and Mathias Trabandt, "The Macroeconomics of Epidemics," Technical Report, National Bureau of Economic Research 2020.

Gelman, M, S Kariv, M D Shapiro, D Silverman, and S Tadelis, "Harnessing Naturally Occurring Data to Measure the Response of Spending to Income," Science, 2014, 345 (6193), $212-215$.

Gormsen, Niels Joachim and Ralph SJ Koijen, "Coronavirus: Impact on Stock Prices and Growth Expectations," University of Chicago, Becker Friedman Institute for Economics Working Paper, 2020, pp. 2020-22. 
Granja, Joao, Christos Makridis, Constantine Yannelis, and Eric Zwick, "Did the Paycheck Protection Program Hit the Target?," National Bureau of Economic Research Working Paper, 2020.

Guerrieri, Veronica, Guido Lorenzoni, Ludwig Straub, and Iván Werning, "Macroeconomic Implications of COVID-19: Can Negative Supply Shocks Cause Demand Shortages?," Technical Report, National Bureau of Economic Research 2020.

Hagedorn, Marcus, Iourii Manovskii, and Kurt Mitman, "The Fiscal Multiplier," Technical Report 2019.

Johnson, David S., Jonathan A. Parker, and Nicholas Souleles, "Household Expenditure and the Income Tax Rebates of 2001," American Economic Review, 2006, 96 (5), 1589-1610.

Jones, Callum, Thomas Philippon, and Venky Venkateswaran, "Optimal Mitigation Policies in a Pandemic," Working Paper, 2020.

Kaplan, Greg and Gianluca Violante, "A Model of the Consumption Response to Fiscal Stimulus Payments," Econometrica, 2014, 82, 1199-1239.

_, Ben Moll, and Gianluca Violante, "Pandemics According to HANK," Technical Report, Working Paper 2020.

Kuchler, T and M Pagel, "Sticking to Your Plan: Hyperbolic Discounting and Credit Card Debt Paydown," Journal of Financial Economics, forthcoming, 2019.

_ and _, "Sticking To Your Plan: Empirical Evidence on the Role of Present Bias for Credit Card Debt Paydown,” Journal of Financial Economics, 2020.

Kueng, Lorenz, "Excess Sensitivity of High-Income Consumers," The Quarterly Journal of Economics, 2018, 133 (4), 1693-1751.

Meyer, Bruce D, "Unemployment Insurance and Unemployment Spells," Econometrica (19861998), 1990, 58 (4), 757.

Misra, Kanishka and Paolo Surico, "Consumption, Income Changes, and Heterogeneity: Evidence from Two Fiscal Stimulus Programs," American Economic Journal: Macroeconomics, 2014, 6 (4), 84-106.

Olafsson, Arna and Michaela Pagel, "The Liquid Hand-to-Mouth: Evidence from Personal Finance Management Software," Review of Financial Studies, 2018, 31 (11), 4398-4446. 
Parker, Jonathan A, Nicholas S Souleles, David S Johnson, and Robert McClelland, "Consumer Spending and the Economic Stimulus Payments of 2008," American Economic Review, 2013, 103 (6), 2530-53. 


\section{Figure 1: Example of Platform}

Notes: The figures show screenshots of the SaverLife website. The upper part of the screenshot shows the app's landing page and the lower part illustrates the offered financial advice pages. Source: SaverLife.
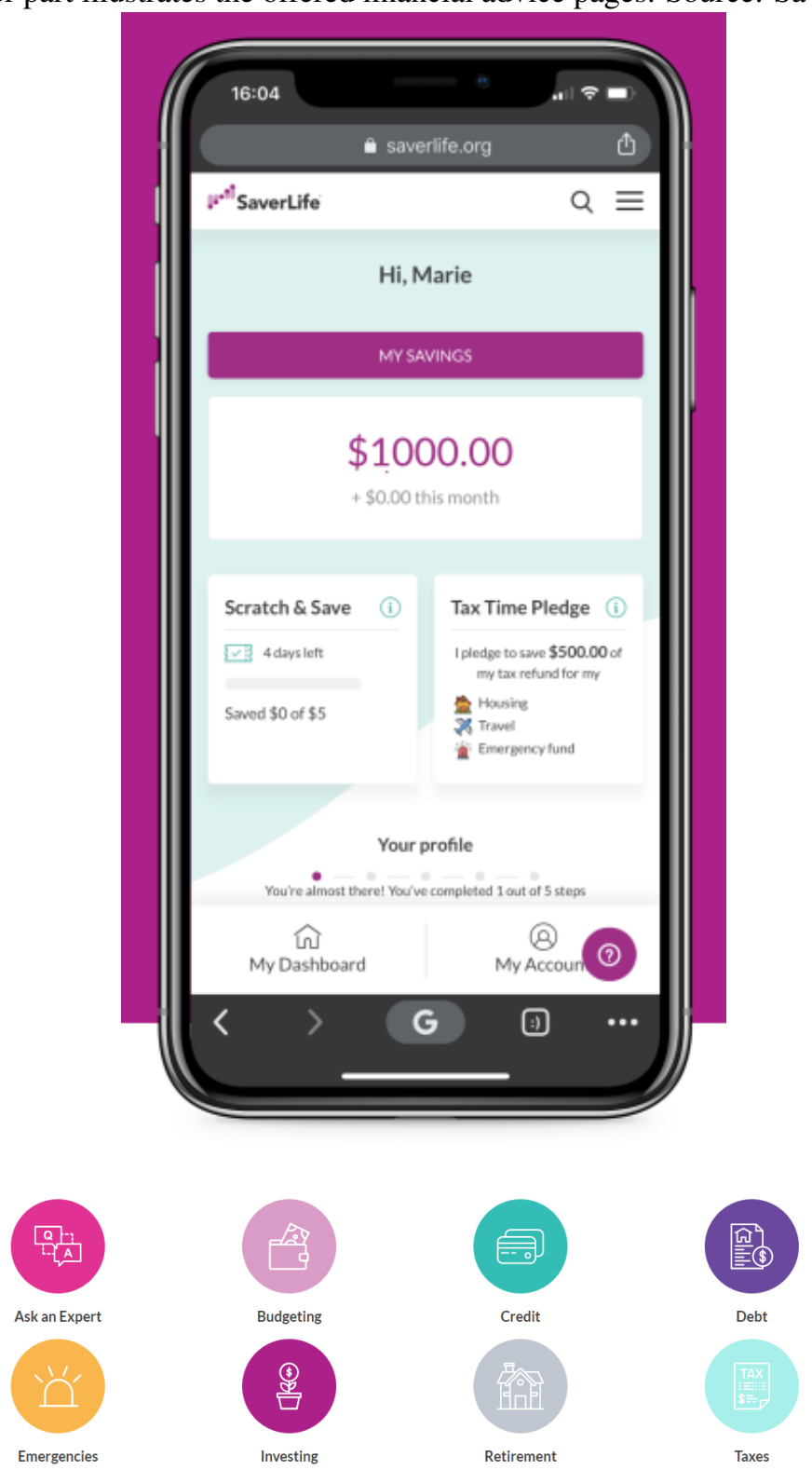


\section{Figure 2: Daily Number of Government Payments at Stimulus Amounts}

Notes: The top panel shows the number of payments users receive that match the amounts of the 2020 government stimulus payment by day in 2019 and 2020 . Potential payments are classified by the specified amounts of the stimulus checks and need to appear as being tax refunds, credit or direct deposits. The bottom panel restricts the time period to February through April in 2020. Source: SaverLife.
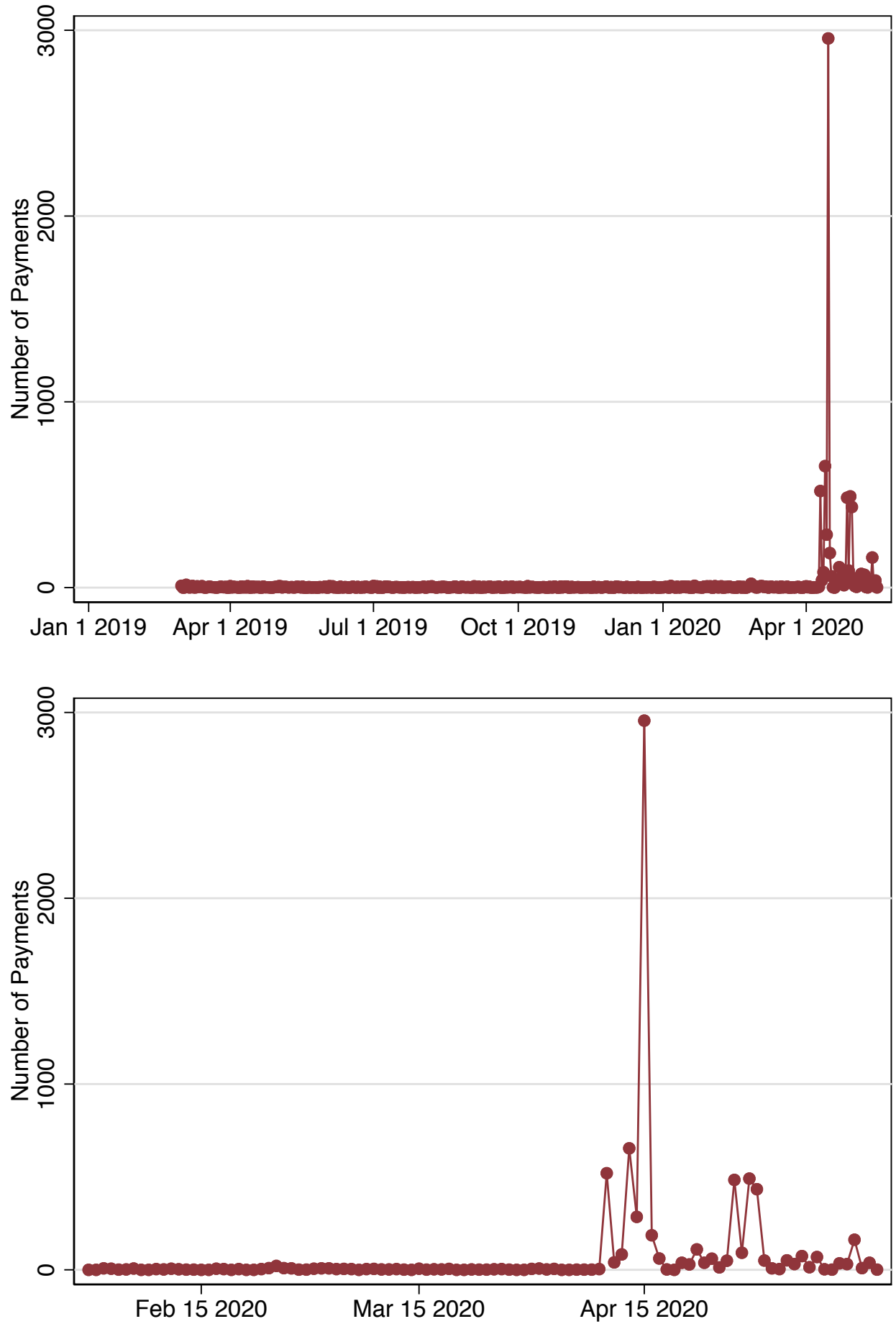
Figure 3: Mean Spending Around Receiving the Stimulus Payments - Raw Spending

Notes: This figure shows mean spending around the receipt of stimulus payments. Sample includes only users who receive a stimulus payment during our sample period. The vertical axis measures spending in dollars, and the horizontal axis shows time in days from receiving the stimulus check which is defined as zero (0). Shaded days represent weekends for the majority of stimulus-recipients who receive their payment on Wednesday April 15th. The graph is based on data from SaverLife.

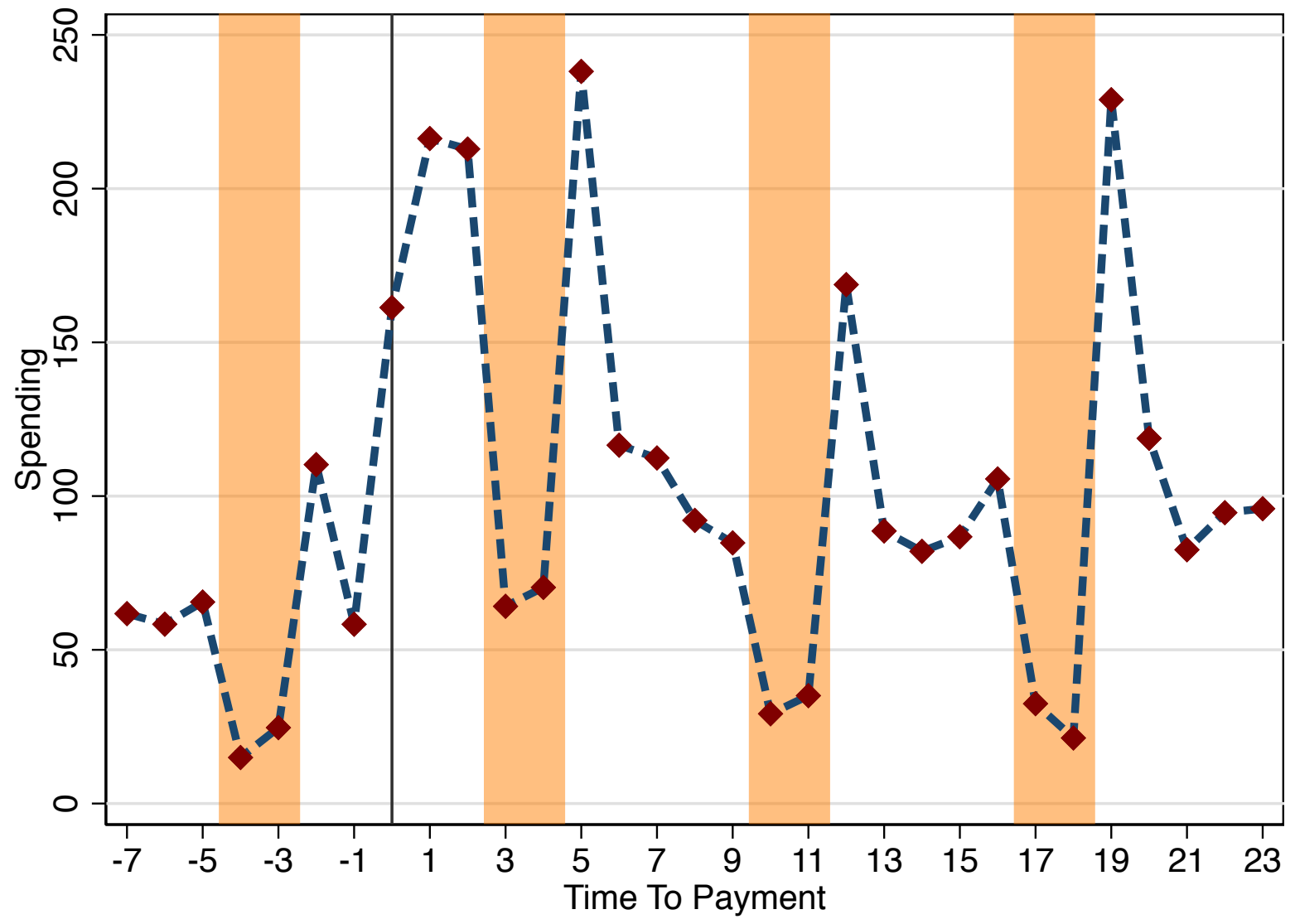


Figure 4: Spending Around Stimulus Payments - Regression Estimates

Notes: This figure shows estimates of $\beta_{i}$ from $c_{i t}=\alpha_{i}+\alpha_{t}+\sum_{t=-7}^{23} \beta_{i} \mathbb{1}[t=i]_{i t}+\varepsilon_{i t}$. Sample includes all users in our sample period (both those who do and do not receive stimulus payments). The solid line shows point estimates of $\beta_{i}$, while the dashed lines show $95 \%$ confidence interval. Time to payment is equal to zero on the day of receiving the stimulus check. Source: SaverLife.

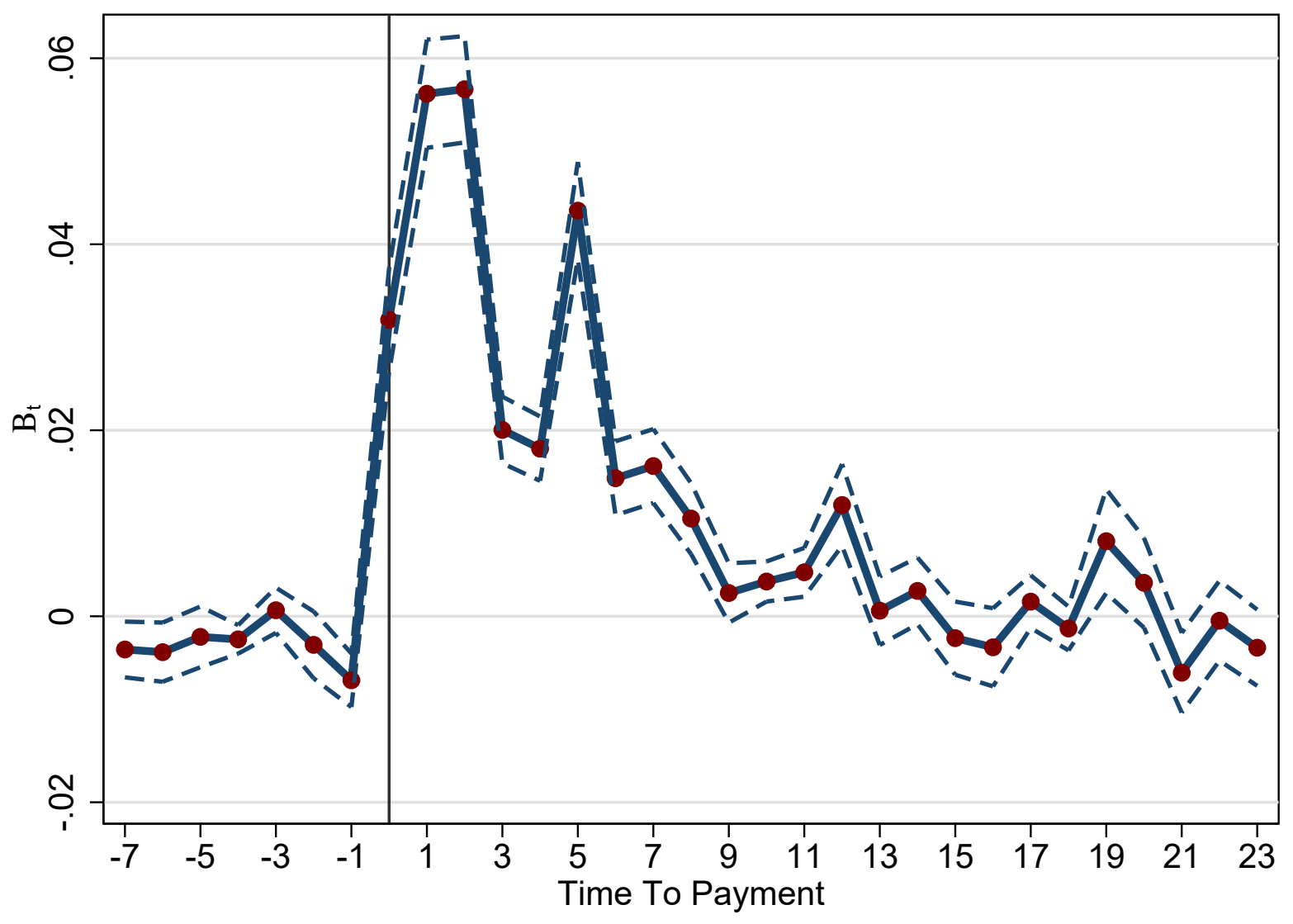




\section{Figure 5: Spending Around Stimulus Payments by Categories}

Notes: This figure shows estimates of $\beta_{i}$ from $c_{i t}=\alpha_{i}+\alpha_{t}+\sum_{t=-7}^{23} \beta_{i} \mathbb{1}[t=i]_{i t}+\varepsilon_{i t}$, broken down by spending categories. The solid line shows point estimates of $\beta_{i}$, while the dashed lines show the $95 \%$ confidence interval. Time to payment is equal to zero on the day of receiving the stimulus check. Source: SaverLife.

Food

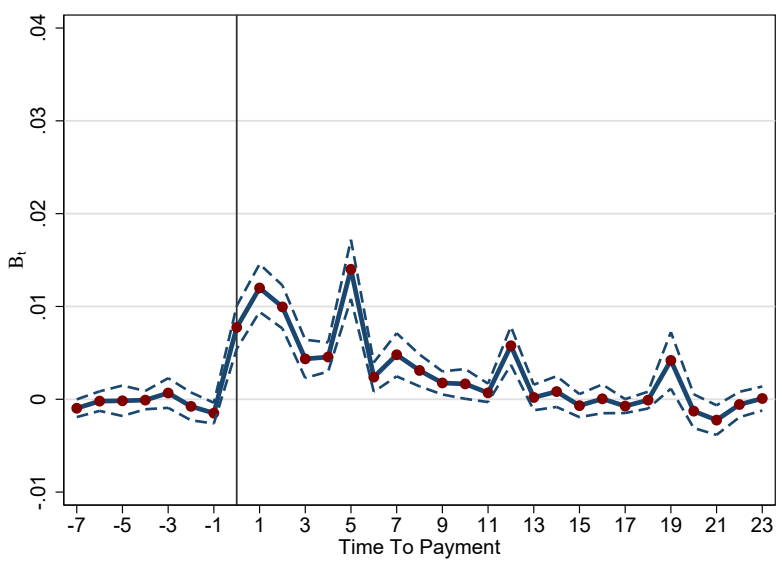

Durables

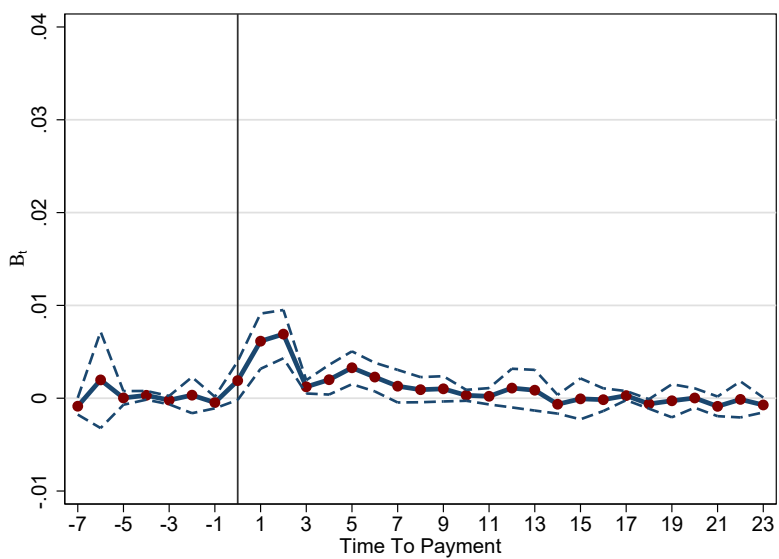

Household

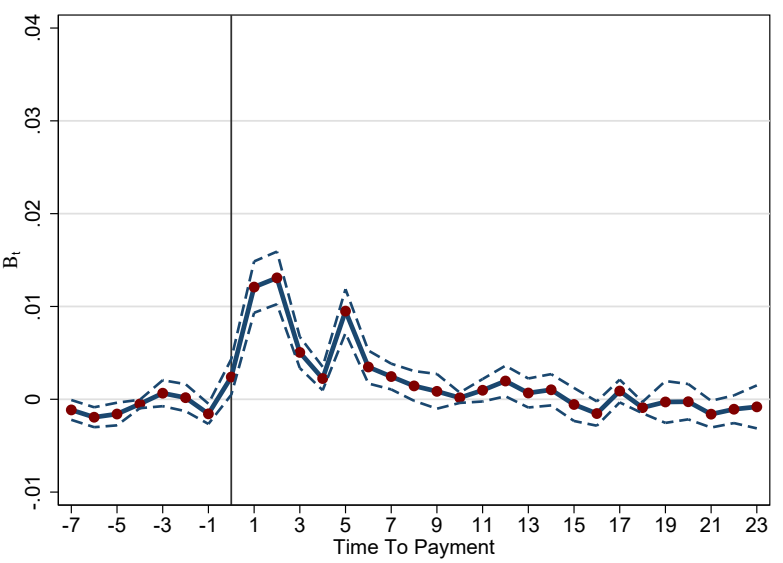

Non-Durables

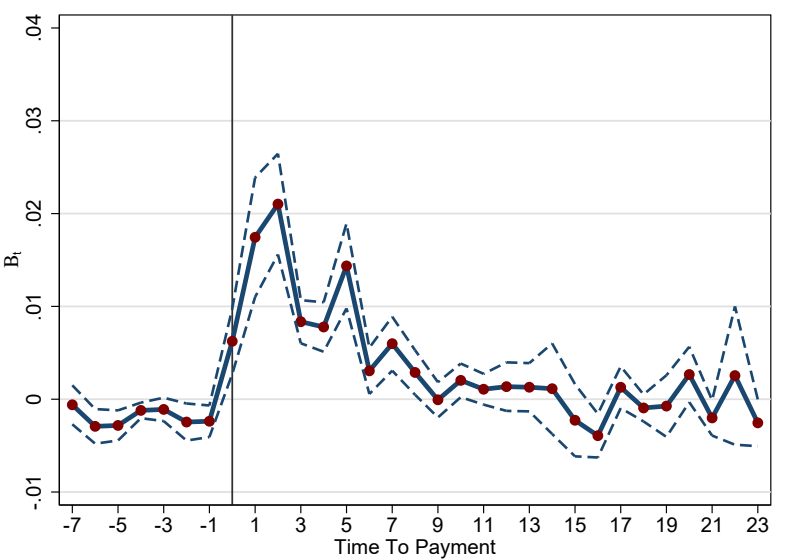

Payments

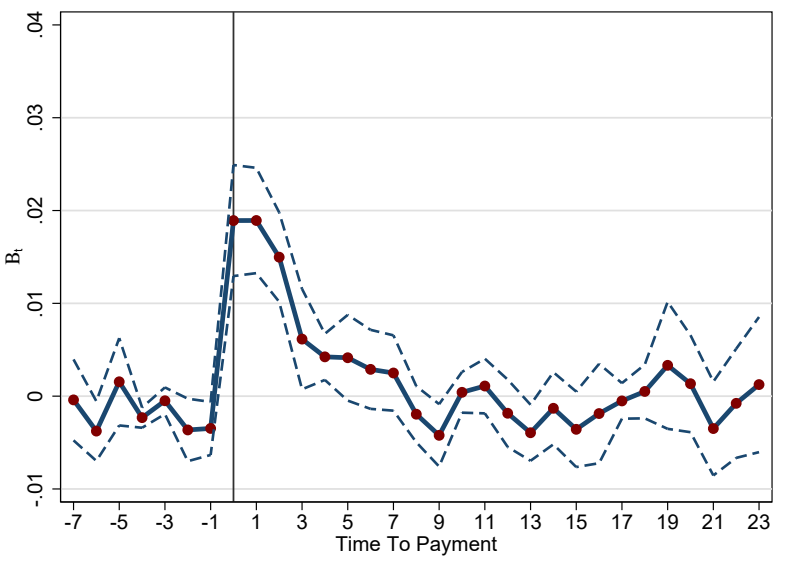




\section{Figure 6: MPC by Income Groups}

Notes: This figure shows cumulative MPCs estimated from coefficients from regressions of spending on an indicator of a time period being after a stimulus payment, scaled by the amount of the payment over the number of days since the payment. That is, of $\zeta$ from $c_{i t}=\alpha_{i}+\alpha_{t}+\zeta \frac{\text { Post }_{i t} \times \text { Stimulus }_{i}}{\text { Days }}+\varepsilon_{i t}$, broken down by monthly income groups. Year and week by individual fixed effects are included. Standard errors are clustered at the user level. The bar shows point estimates, while the thin lines show the $95 \%$ confidence interval. Source: SaverLife.

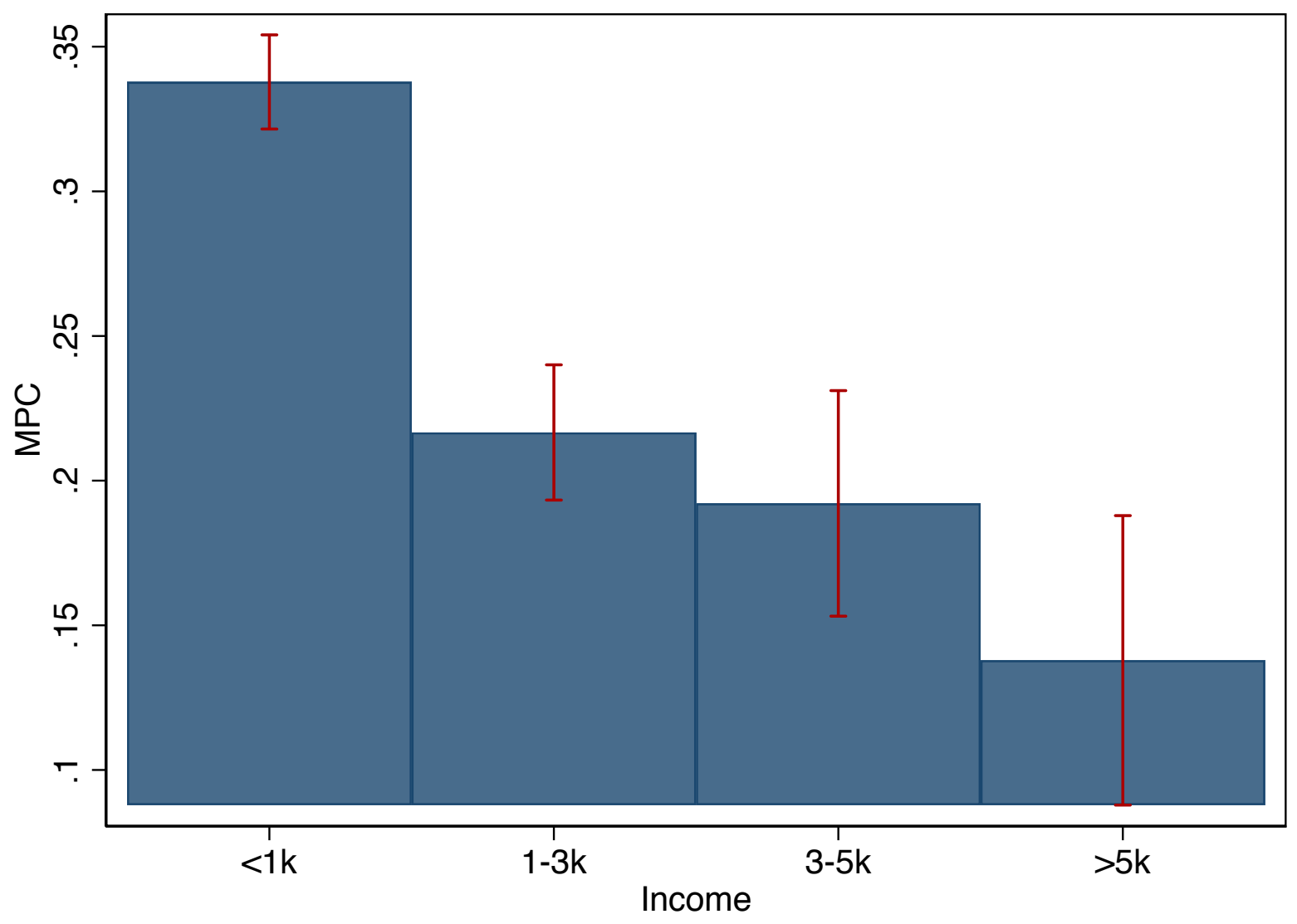




\section{Figure 7: MPC by Liquidity}

Notes: This figure shows cumulative MPCs estimated from coefficients from regressions of spending on an indicator of a time period being after a stimulus payment, scaled by the amount of the payment over the number of days since the payment. That is, of $\zeta$ from $c_{i t}=\alpha_{i}+\alpha_{t}+\zeta \frac{\text { Postit }_{i t} \times \text { Stimulus }_{i}}{\text { Days } s_{i t}}+\varepsilon_{i t}$, broken down by account balances. Year and week by individual fixed effects are included. Standard errors are clustered at the user level. The bar shows point estimates, while the thin lines show 95\% confidence interval. Source: SaverLife.

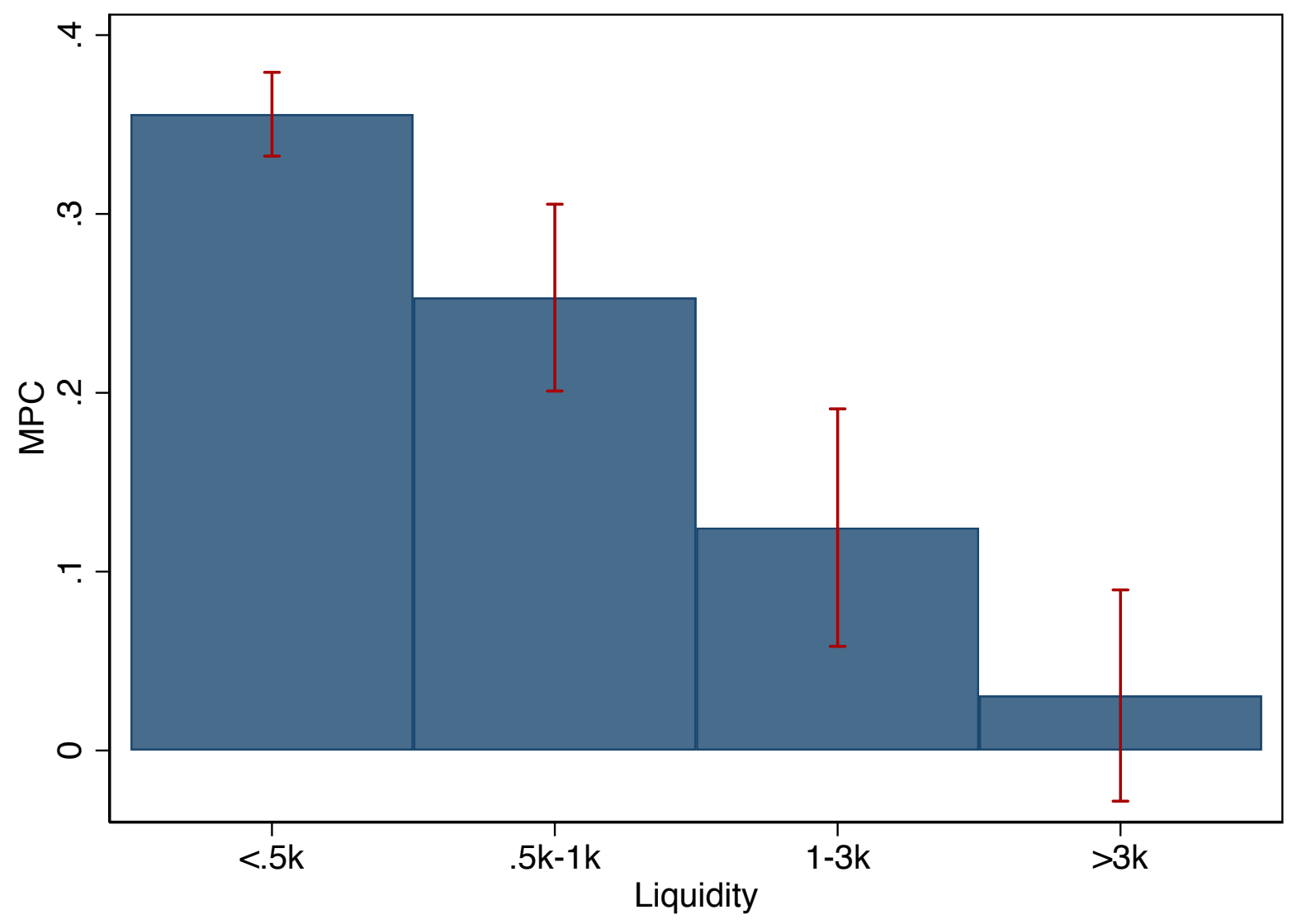




\section{Figure 8: MPC by Drop in Income}

Notes: This figure shows cumulative MPCs estimated from coefficients from regressions of spending on an indicator of a time period being after a stimulus payment, scaled by the amount of the payment over the number of days since the payment. That is, of $\zeta$ from $c_{i t}=\alpha_{i}+\alpha_{t}+\zeta \frac{\text { Postit }_{i t} \times \text { Stimulus }_{i}}{\text { Daysit }}+\varepsilon_{i t}$, broken down by the drop in income between January/February 2020 and March 2020. Year and week by individual fixed effects are included. Standard errors are clustered at the user level. The bar shows point estimates, while the thin lines show $95 \%$ confidence interval. Source: SaverLife.

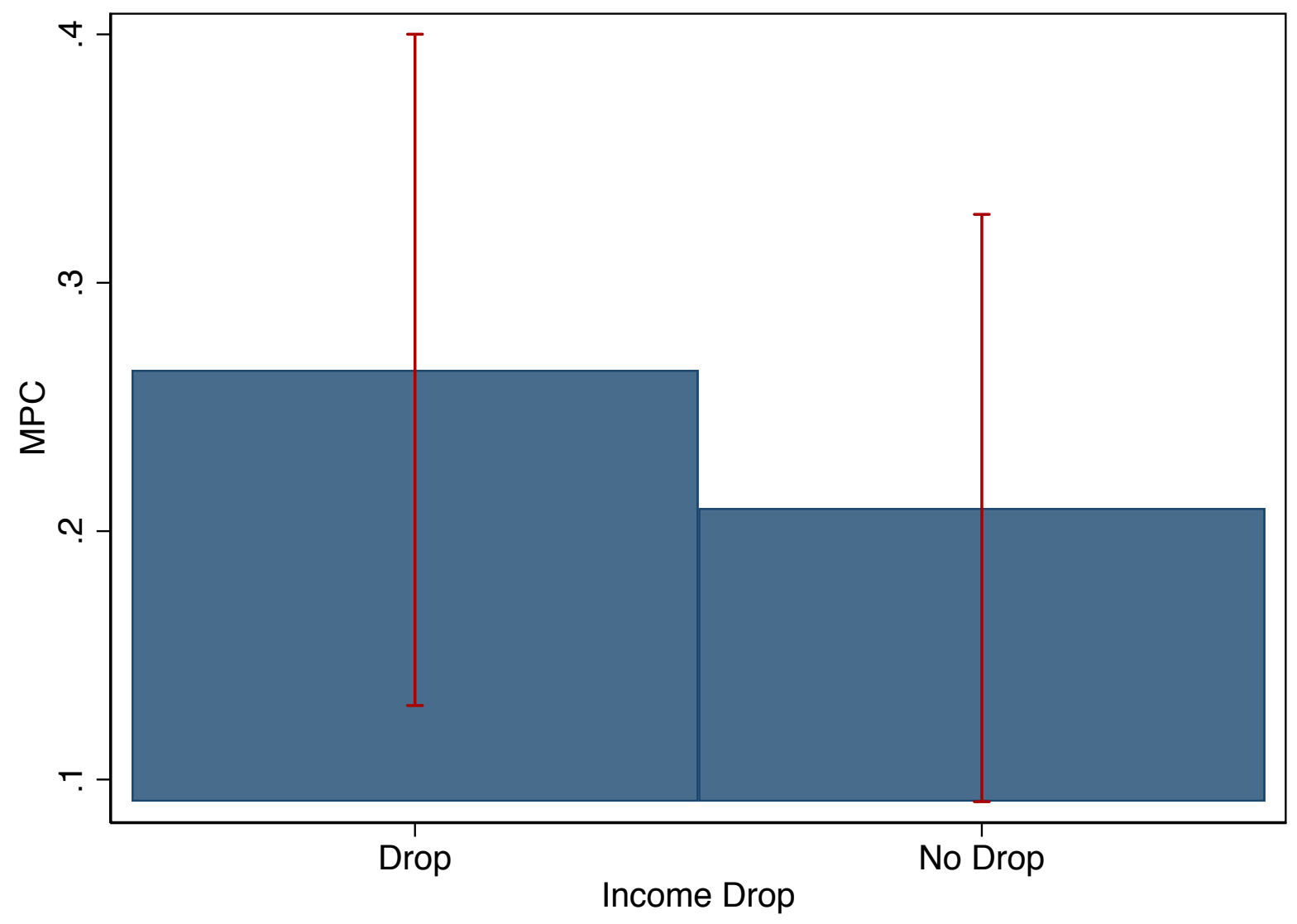


Figure 9: Payment Spending Around Stimulus

Notes: This figure shows estimates of $\beta_{i}$ from $c_{i t}=\alpha_{i}+\alpha_{t}+\sum_{t=-7}^{23} \beta_{i} \mathbb{1}[t=i]_{i t}+\varepsilon_{i t}$, broken down by payment categories. The solid line shows point estimates of $\beta_{i}$, while the dashed lines show the $95 \%$ confidence interval. Time to payment is equal to zero on the day of receiving the stimulus check. Source: SaverLife.

Total Financial Payments

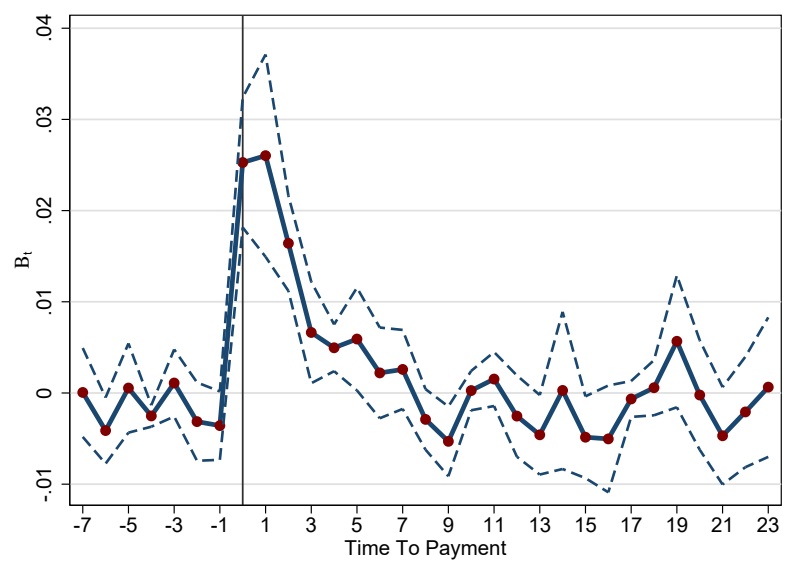

Mortgage \& Rent

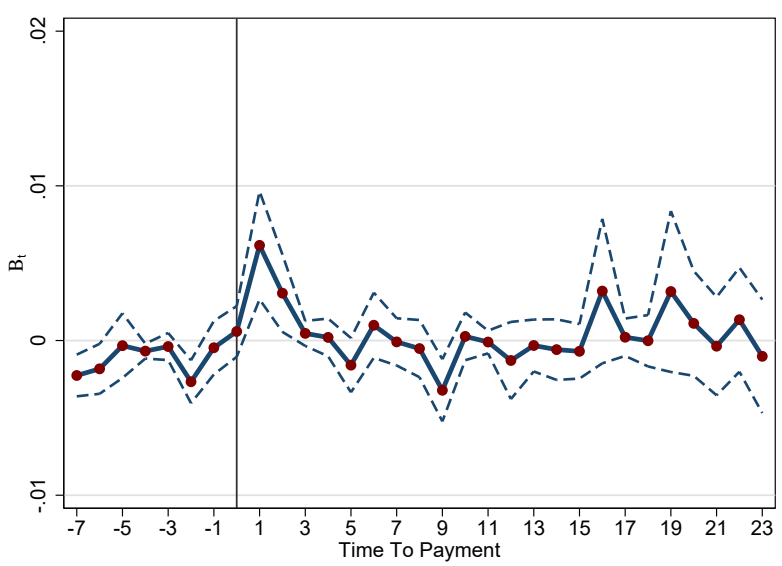

Credit Card Payments

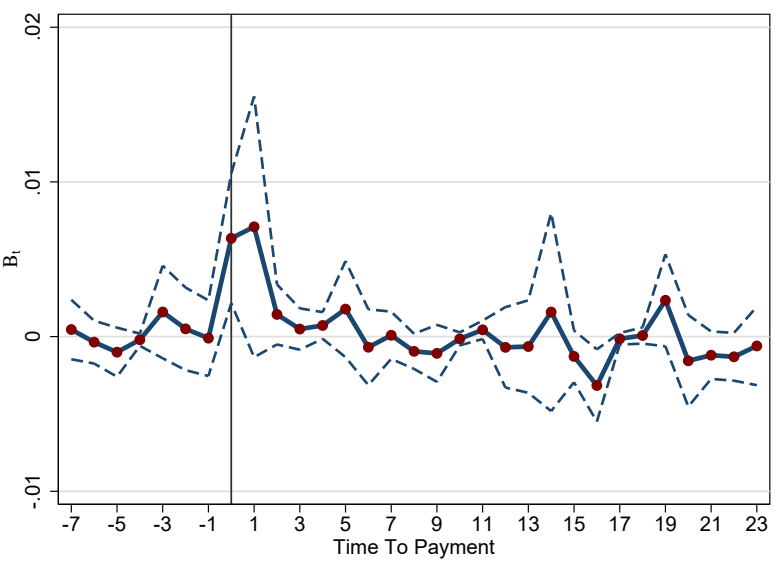

Non-Credit Card Payments

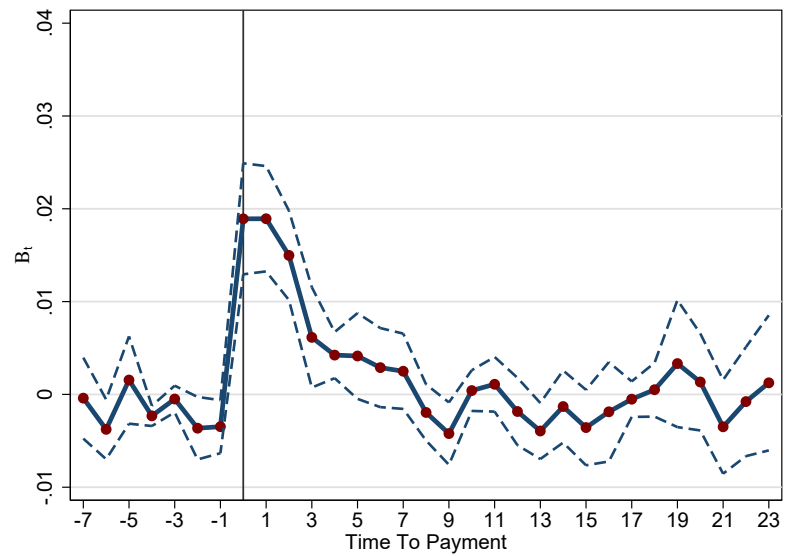


Table 1: Summary Statistics

Notes: Summary statistics for spending and income represent user-month observations. Statistics regarding user characteristics are given at a user level. Stimulus Income (Cond) refers to the distribution of Stimulus income conditional on receiving a stimulus payment.

\begin{tabular}{|c|c|c|c|c|c|c|c|}
\hline Variable & \# Obs. & Mean & 10th & 25 th & Median & 75th & 90th \\
\hline \multicolumn{8}{|c|}{ User-Month } \\
\hline Income & 22,826 & $1,913.87$ & 100 & 600.96 & $1,562.76$ & $2,982.05$ & $4,662.17$ \\
\hline Balance & 22,826 & 650.42 & 3.91 & 38.48 & 148.30 & 825.73 & $2,451.86$ \\
\hline Durables & 22,826 & 48.41 & 0 & 0 & 0 & 30 & 159.90 \\
\hline Food & 22,826 & 242.07 & 0 & 21.185 & 151.315 & 371.25 & 651.02 \\
\hline Household & 22,826 & 225.11 & 0 & 30 & 151.22 & 350.82 & 598.39 \\
\hline Non-durables & 22,826 & 320.37 & 0 & 50.32 & 213.53 & 478.39 & 850.16 \\
\hline Payments & 22,826 & 402.93 & 0 & 0 & 132.61 & 659.48 & $1,278.29$ \\
\hline Transfers & 22,826 & 515.74 & 0 & 31.98 & 256.39 & 801.44 & $1,521.58$ \\
\hline \multicolumn{8}{|c|}{ User } \\
\hline Stimulus Income & 6,033 & 840.85 & 0 & 0 & 0 & 1,200 & 2,400 \\
\hline Stimulus Income (Cond) & 2,665 & $1,903.52$ & 1,200 & 1,200 & 1,700 & 2,200 & 3,200 \\
\hline
\end{tabular}




\section{Table 2: Stimulus Payments and Spending}

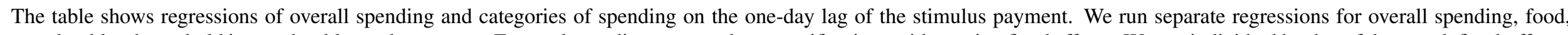

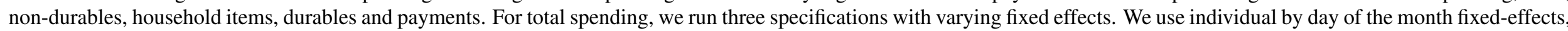
individual and calendar date and individual times day of month fixed-effects, or individual and day of the month and individual times day of week fixed-effects. Standard errors are clustered at the user level. ${ }^{*} p<.1,{ }^{* *} p<.05$, $* * * p<.01$. Source: SaverLife.

\begin{tabular}{|c|c|c|c|c|c|c|c|c|}
\hline & $\begin{array}{l}\text { (1) } \\
\text { Total }\end{array}$ & $\begin{array}{l}\text { (2) } \\
\text { Total }\end{array}$ & $\begin{array}{l}\text { (3) } \\
\text { Total }\end{array}$ & $\begin{array}{l}\text { (4) } \\
\text { Food }\end{array}$ & $\begin{array}{c}\text { (5) } \\
\text { NonDurables }\end{array}$ & $\begin{array}{c}\text { (6) } \\
\text { Household }\end{array}$ & $\begin{array}{c}(7) \\
\text { Durables }\end{array}$ & $\begin{array}{c}(8) \\
\text { Payments }\end{array}$ \\
\hline Stimulus Payment & $\begin{array}{l}0.0310^{* * *} \\
(0.00552)\end{array}$ & $\begin{array}{l}0.0345^{* * *} \\
(0.00391)\end{array}$ & $\begin{array}{l}0.0396^{* * *} \\
(0.00469)\end{array}$ & $\begin{array}{c}0.00731^{* * *} \\
(0.00126)\end{array}$ & $\begin{array}{c}0.00527^{*} \\
(0.00284)\end{array}$ & $\begin{array}{l}0.00259^{* *} \\
(0.00105)\end{array}$ & $\begin{array}{l}0.00216^{* *} \\
(0.000966)\end{array}$ & $\begin{array}{l}0.0195^{* * *} \\
(0.00528)\end{array}$ \\
\hline Stimulus Payment $_{t+1}$ & $\begin{array}{l}0.0599^{* * *} \\
(0.00604)\end{array}$ & $\begin{array}{l}0.0590^{* * *} \\
(0.00563)\end{array}$ & $\begin{array}{l}0.0589^{* * *} \\
(0.00768)\end{array}$ & $\begin{array}{l}0.0125^{* * *} \\
(0.00225)\end{array}$ & $\begin{array}{l}0.0188^{* * *} \\
(0.00298)\end{array}$ & $\begin{array}{l}0.0128^{* * *} \\
(0.00263)\end{array}$ & $\begin{array}{c}0.00713^{* * *} \\
(0.00143)\end{array}$ & $\begin{array}{l}0.0219^{* * *} \\
(0.00408)\end{array}$ \\
\hline Stimulus Payment $_{t+2}$ & $\begin{array}{c}0.0603^{* * *} \\
(0.0163)\end{array}$ & $\begin{array}{c}0.0578^{* * *} \\
(0.0161)\end{array}$ & $\begin{array}{c}0.0626^{* * *} \\
(0.0137)\end{array}$ & $\begin{array}{c}0.00993^{* * *} \\
(0.00309)\end{array}$ & $\begin{array}{c}0.0218^{* *} \\
(0.00822)\end{array}$ & $\begin{array}{c}0.0141^{*} \\
(0.00779)\end{array}$ & $\begin{array}{c}0.00705^{* * *} \\
(0.00174)\end{array}$ & $\begin{array}{l}0.0168^{* * *} \\
(0.00456)\end{array}$ \\
\hline Stimulus Payment $_{t+3}$ & $\begin{array}{l}0.00835 \\
(0.0166)\end{array}$ & $\begin{array}{c}0.0205 \\
(0.0140)\end{array}$ & $\begin{array}{l}0.00484 \\
(0.0179)\end{array}$ & $\begin{array}{c}0.00185 \\
(0.00646)\end{array}$ & $\begin{array}{c}0.00520 \\
(0.00714)\end{array}$ & $\begin{array}{c}0.00262 \\
(0.00612)\end{array}$ & $\begin{array}{c}0.000123 \\
(0.000743)\end{array}$ & $\begin{array}{c}0.00203 \\
(0.00756)\end{array}$ \\
\hline Stimulus Payment $_{t+4}$ & $\begin{array}{l}0.00808 \\
(0.0172)\end{array}$ & $\begin{array}{c}0.0185 \\
(0.0131)\end{array}$ & $\begin{array}{l}0.00875 \\
(0.0144)\end{array}$ & $\begin{array}{c}0.00226 \\
(0.00658)\end{array}$ & $\begin{array}{c}0.00577 \\
(0.00836)\end{array}$ & $\begin{array}{l}0.000525 \\
(0.00365)\end{array}$ & $\begin{array}{c}0.00180 \\
(0.00285)\end{array}$ & $\begin{array}{l}0.000347 \\
(0.00573)\end{array}$ \\
\hline Stimulus Payment $_{t+5}$ & $\begin{array}{c}0.0609^{* * *} \\
(0.0114)\end{array}$ & $\begin{array}{l}0.0440^{* * *} \\
(0.00807)\end{array}$ & $\begin{array}{c}0.0644^{* * *} \\
(0.0101)\end{array}$ & $\begin{array}{c}0.0192^{* *} \\
(0.00904)\end{array}$ & $\begin{array}{l}0.0203^{* * *} \\
(0.00432)\end{array}$ & $\begin{array}{l}0.0125^{* *} \\
(0.00486)\end{array}$ & $\begin{array}{c}0.00463^{* *} \\
(0.00186)\end{array}$ & $\begin{array}{l}0.0112^{* * *} \\
(0.00309)\end{array}$ \\
\hline Stimulus Payment $_{t+6}$ & $\begin{array}{l}0.0216^{* * *} \\
(0.00440)\end{array}$ & $\begin{array}{l}0.0162^{* * *} \\
(0.00488)\end{array}$ & $\begin{array}{l}0.0196^{* * *} \\
(0.00496)\end{array}$ & $\begin{array}{c}0.00390^{* *} \\
(0.00158)\end{array}$ & $\begin{array}{c}0.00591^{* *} \\
(0.00244)\end{array}$ & $\begin{array}{c}0.00526^{* * *} \\
(0.00124)\end{array}$ & $\begin{array}{l}0.00241^{* * *} \\
(0.000571)\end{array}$ & $\begin{array}{c}0.00502^{* * *} \\
(0.00139)\end{array}$ \\
\hline Stimulus Payment $_{t+7}$ & $\begin{array}{l}0.0140^{* * *} \\
(0.00346)\end{array}$ & $\begin{array}{l}0.0172^{* * *} \\
(0.00398)\end{array}$ & $\begin{array}{l}0.0213^{* * *} \\
(0.00388)\end{array}$ & $\begin{array}{c}0.00372^{* *} \\
(0.00144)\end{array}$ & $\begin{array}{c}0.00444^{* * *} \\
(0.00143)\end{array}$ & $\begin{array}{l}0.00281^{* * *} \\
(0.000926)\end{array}$ & $\begin{array}{c}0.00150^{* *} \\
(0.000586)\end{array}$ & $\begin{array}{c}0.00243 \\
(0.00194)\end{array}$ \\
\hline Stimulus Payment $_{t+8}$ & $\begin{array}{l}0.0130^{* * *} \\
(0.00326)\end{array}$ & $\begin{array}{l}0.0118^{* * *} \\
(0.00359)\end{array}$ & $\begin{array}{c}0.0138^{* *} \\
(0.00540)\end{array}$ & $\begin{array}{l}0.00370^{* * *} \\
(0.000920)\end{array}$ & $\begin{array}{c}0.00396^{* * *} \\
(0.00130)\end{array}$ & $\begin{array}{c}0.00255^{* * *} \\
(0.000861)\end{array}$ & $\begin{array}{l}0.00119^{* * *} \\
(0.000402)\end{array}$ & $\begin{array}{c}0.00103 \\
(0.00140)\end{array}$ \\
\hline Stimulus Payment $_{t+9}$ & $\begin{array}{l}0.00603^{* *} \\
(0.00282)\end{array}$ & $\begin{array}{c}0.00327 \\
(0.00250)\end{array}$ & $\begin{array}{c}0.00155 \\
(0.00508)\end{array}$ & $\begin{array}{c}0.00160 \\
(0.000970)\end{array}$ & $\begin{array}{c}0.00131 \\
(0.00140)\end{array}$ & $\begin{array}{c}0.00171^{* *} \\
(0.000798)\end{array}$ & $\begin{array}{l}0.000963^{* *} \\
(0.000392)\end{array}$ & $\begin{array}{l}-0.00112 \\
(0.00157)\end{array}$ \\
\hline Date FE & YES & YES & YES & YES & YES & YES & YES & YES \\
\hline User FE & YES & YES & YES & YES & YES & YES & YES & YES \\
\hline User*Day of Week FE & NO & YES & NO & NO & NO & NO & NO & NO \\
\hline User*Day of Month FE & NO & NO & YES & NO & NO & NO & NO & NO \\
\hline Observations & 560,711 & 560,711 & 560,711 & 560,711 & 560,711 & 560,711 & 560,711 & 560,711 \\
\hline$R^{2}$ & 0.178 & 0.291 & 0.409 & 0.080 & 0.062 & 0.077 & 0.024 & 0.051 \\
\hline
\end{tabular}


Table 3: Stimulus Payments, Spending and Income

This figure shows cumulative MPCs estimated from coefficients from regressions of spending on an indicator of a time period being after a stimulus payment, scaled by the amount of the payment over the number of days since the payment. That is, of $\zeta$ and $\xi$ from $c_{i t}=\alpha_{i}+\alpha_{t}+\zeta \frac{\text { Post }_{i t} \times \text { Stimulus }_{i}}{D a y s}+\xi \frac{\text { Post }_{i t} \times \text { Stimulus }_{i}}{\text { Says }_{i}} \times I_{i}+\phi$ Post $_{i t} \times I_{i}+\varepsilon_{i t}$. Average monthly income is approximately $\$ 1,700$, yielding a logged income value of 7.4. Columns (4) and (5) drop the interaction, and split the sample by January and February monthly income above and below $\$ 2,000$. The inclusion of fixed effects is denoted beneath each specification. Standard errors are clustered at the user level. ${ }^{*} p<.1,{ }^{* *} p<.05, * * * p<.01$. Source: SaverLife.

\begin{tabular}{lccccc}
\hline \hline & $(1)$ & $(2)$ & $(3)$ & $(4)$ & $(5)$ \\
& Total & Total & Total & Low Inc & High Inc \\
\hline Post-Stimulus*Stimulus & $0.703^{* * *}$ & $0.732^{* * *}$ & $0.684^{* * *}$ & $0.337^{* * *}$ & $0.180^{* *}$ \\
& $(0.129)$ & $(0.0993)$ & $(0.132)$ & $(0.0534)$ & $(0.0803)$ \\
Post-Stimulus*Stimulus*ln(Inc) & $-0.0629^{* * *}$ & $-0.0656^{* * *}$ & $-0.0593^{* *}$ & & \\
& $(0.0213)$ & $(0.0152)$ & $(0.0228)$ & & \\
\hline Date & $\mathbf{X}$ & $\mathbf{X}$ & $\mathbf{X}$ & $\mathbf{X}$ & $\mathbf{X}$ \\
Individual FE & $\mathbf{X}$ & $\mathbf{X}$ & $\mathbf{X}$ & $\mathbf{X}$ & $\mathbf{X}$ \\
Individual X Day of Month FE & & $\mathbf{X}$ & & & \\
Individual X Day of Week FE & & & $\mathbf{X}$ & $\mathbf{X}$ & $\mathbf{X}$ \\
Observations & 560,711 & 560,711 & 560,711 & 350,177 & 210,534 \\
$R^{2}$ & 0.172 & 0.287 & 0.404 & 0.130 & 0.196 \\
\hline \hline
\end{tabular}




\section{Table 4: Stimulus Payments, Spending and Liquidity}

This figure shows cumulative MPCs estimated from coefficients from regressions of spending on an indicator of a time period being after a stimulus payment, scaled by the amount of the payment over the number of days since the payment. That is, of $\zeta$ and $\xi$ from $c_{i t}=\alpha_{i}+\alpha_{t}+\zeta \frac{\text { Post }_{i t} \times \text { Stimulus }_{i}}{\text { Days }_{i t}}+\xi \frac{\text { Post }_{i t} \times \text { Stimulus }_{i}}{\text { Days }_{i t}} \times L_{i}+\phi$ Post $_{i t} \times L_{i}+\varepsilon_{i t}$. The second row of columns (1) through (3) interacts with the individual's bank account balance prior to the arrival of the stimulus payment, in thousands of dollars. Columns (4) and (5) drop the interaction, and split the sample by having more or less than $\$ 500$ in a bank account. Columns (6) and (7) does the same split as in columns (4) and (4), restricting to individuals who make more than $\$ 5,000$ a month.. The inclusion of fixed effects is denoted beneath each specification. Standard errors are clustered at the user level. $* p<.1$, $* * p<.05$, *** $p<.01$. Source: SaverLife.

\begin{tabular}{|c|c|c|c|c|c|c|c|}
\hline & $(1)$ & $(2)$ & $(3)$ & (4) & $(5)$ & $(6)$ & $(7)$ \\
\hline & Total & Total & Total & Low Bal & High Bal & High Inc/Low Bal & High Inc/High Bal \\
\hline \multirow[t]{2}{*}{ Post-Stimulus*Stimulus } & $0.293^{* * *}$ & $0.300^{* * *}$ & $0.297^{* * *}$ & $0.330^{* * *}$ & $0.181^{* * *}$ & $0.309^{*}$ & $0.107^{* *}$ \\
\hline & $(0.0438)$ & $(0.0435)$ & $(0.0424)$ & $(0.0627)$ & $(0.0590)$ & $(0.182)$ & $(0.0444)$ \\
\hline Post-Stimulus*Stimulus*Balance & $\begin{array}{c}-0.0665^{* *} \\
(0.0248)\end{array}$ & $\begin{array}{c}-0.0690^{* * *} \\
(0.0199)\end{array}$ & $\begin{array}{c}-0.0562^{* *} \\
(0.0240)\end{array}$ & & & & \\
\hline Date & $\mathbf{X}$ & $\mathbf{X}$ & $\mathbf{X}$ & $\mathbf{X}$ & $\mathbf{X}$ & $\mathbf{X}$ & $\mathbf{X}$ \\
\hline Individual FE & $\mathbf{X}$ & $\mathbf{X}$ & $\mathbf{X}$ & $\mathbf{X}$ & $\mathbf{X}$ & $\mathbf{X}$ & $\mathbf{X}$ \\
\hline Individual X Day of Month FE & & $\mathbf{X}$ & & & & & \\
\hline Individual X Day of Week FE & & & $\mathbf{X}$ & $\mathbf{X}$ & $\mathbf{X}$ & & \\
\hline Observations & 560,711 & 560,711 & 560,711 & 261,669 & 299,042 & 19,631 & 39,508 \\
\hline$R^{2}$ & 0.172 & 0.287 & 0.404 & 0.138 & 0.202 & 0.226 & 0.244 \\
\hline
\end{tabular}




\section{Table 5: Stimulus Payments, Spending and Income Declines}

This figure shows cumulative MPCs estimated from coefficients from regressions of spending on an indicator of a time period being after a stimulus payment, scaled by the amount of the payment over the number of days since the payment. That is, of $\zeta$ and $\xi$ from $c_{i t}=\alpha_{i}+\alpha_{t}+\zeta \frac{\text { Post }_{i t} \times \text { Stimulus }_{i}}{\text { Days }_{i t}}+\xi \frac{\text { Post }_{i t} \times \text { Stimulus }_{i}}{\text { Days }_{i t}} \times D_{i}+\phi$ Post $_{i t} \times D_{i}+\varepsilon_{i t}$. The second row of columns (1) through (3) interacts with the fraction of January income that an individual earned in March. Columns (4) and (5) drop the interaction, and split the sample by income drops between January and February versus March, separately examining the top and bottom quartiles of income declines in this period. The inclusion of fixed effects is denoted beneath each specification. Standard errors are clustered at the user level. * $p<.1$, ** $p<.05, * * * p<.01$. Source: SaverLife.

\begin{tabular}{lccccc}
\hline \hline & $(1)$ & $(2)$ & $(3)$ & $(4)$ & $(5)$ \\
& Total & Total & Total & Income Decline & No Decline \\
\hline Post-Stimulus*Stimulus & $0.231^{* * *}$ & $0.238^{* * *}$ & $0.233^{* * *}$ & $0.265^{* * *}$ & $0.209^{* * *}$ \\
& $(0.0620)$ & $(0.0468)$ & $(0.0583)$ & $(0.0689)$ & $(0.0603)$
\end{tabular}

\begin{tabular}{lccccc} 
Post-Stimulus*Stimulus*Inc Drop & $-0.0341^{* *}$ & $-0.0374^{* *}$ & -0.0265 & & \\
& $(0.0164)$ & $(0.0164)$ & $(0.0165)$ & & $\mathbf{X}$ \\
\hline Date & $\mathbf{X}$ & $\mathbf{X}$ & $\mathbf{X}$ & $\mathbf{X}$ & $\mathbf{X}$ \\
Individual FE & $\mathbf{X}$ & $\mathbf{X}$ & $\mathbf{X}$ & $\mathbf{X}$ & $\mathbf{X}$ \\
Individual X Day of Month FE & & $\mathbf{X}$ & & & $\mathbf{X}$ \\
Individual X Day of Week FE & & & $\mathbf{X}$ & $\mathbf{X}$ & 259,574 \\
Observations & 560,711 & 560,711 & 560,711 & 301,137 & 0.169 \\
$R^{2}$ & 0.172 & 0.287 & 0.404 & 0.179 & \\
\hline \hline
\end{tabular}


Table 6: Payments

This figure shows cumulative MPCs estimated from coefficients from regressions of spending on an indicator of a time period being after a stimulus payment, scaled by the amount of the payment over the number of days since the payment. That is, of $\zeta$ and $\xi$ from $c_{i t}=\alpha_{i}+\alpha_{t}+\zeta \frac{\text { Post }_{i t} \times \text { Stimulus }_{i}}{D}+\varepsilon_{i t}$. Each column shows a different payment category. The inclusion of fixed effects is denoted beneath each specification. Standard errors are clustered at the user level. ${ }^{*} p<.1, * * p<.05$, $* * * p<.01$. Source: SaverLife.

(1)

(2)

(3)

(4)

(5)

Total Spending Total Financial Payments CC Payments Non-CC Payment Rent and Mortgage

\begin{tabular}{lccccc} 
& Total Spending & Total Financial Payments & CC Payments & Non-CC Payment & $0.00937^{*}$ \\
& $0.236^{* * *}$ & $0.0752^{* * *}$ & $0.0609^{* * *}$ & 0.0143 & $(0.00532)$ \\
\hline Date & $(0.0321)$ & $(0.0194)$ & $(0.0142)$ & $\mathbf{X}$ & $\mathbf{X}$ \\
Individual FE & $\mathbf{X}$ & $\mathbf{X}$ & $\mathbf{X}$ & $\mathbf{X}$ & $\mathbf{X}$ \\
Observations & $\mathbf{X}$ & $\mathbf{X}$ & 571,089 & 571,089 & $\mathbf{X}$ \\
$R^{2}$ & 571,089 & 571,089 & 0.123 & 0.127 & 0.113 \\
\hline \hline
\end{tabular}




\section{A Details on the CARES Act}

The COVID-19 pandemic and the following policy responses had a large impact on the US economy. To combat the adverse consequences, Congress passed the Coronavirus Aid, Relief and Economic Security Act (CARES Act) which was signed into law on March 27, 2020. The CARES Act is the third act in a sequence of responses to the outbreak of the coronavirus by Congress. The first act was focused on spurring coronavirus vaccine research and development (Coronavirus Preparedness and Response Supplemental Appropriations Act, March 6, 2020) with a volume of $\$ 8.2$ billion. The second act was a package of approximately \$104 billion in paid sick leave and unemployment benefits for workers and families (the Families First Coronavirus Response Act, March 18, 2020).

The CARES Act was a $\$ 2.2$ trillion economic stimulus package and is by far the largest part in this sequence of responses to the pandemic up to that point. The act splits up into $\$ 500$ billion support for companies in distress, $\$ 350$ billion in loans for small businesses, and over $\$ 300$ billion in stimulus payments for most American workers. The rebate provides a direct payment, which is treated as a refundable tax credit against 2020 personal income taxes. Thus, the rebates would not be counted as taxable income for recipients, as the rebate is a credit against tax liability and is refundable for taxpayers with no tax liability to offset. Figure A.1 shows an example of a letter send out announcing stimulus payments.

All individuals were eligible for the stimulus if they had a valid social security number and if they were not depending on someone else. Individuals must have filed tax returns in 2018 or 2019. Individuals who did not need to file tax returns because their income was below $\$ 12,200(\$ 24,400$ for married couples) were eligible but needed to register through a website at the Internal Revenue Service. Recipients of social security benefits did not need to register but were also eligible.

Single individuals received up to $\$ 1,200$, while those who filed jointly received $\$ 2,400$. Additionally, individuals with children under 17 received an add-on of $\$ 500$ per child. The tax rebate phased out for higher levels of income. The payment was declined by 5 percent of the amount of adjusted gross income. The phase-out started at $\$ 75,000$ for singles or at $\$ 150,000$ for married couples. For households heads with dependents (e.g. one person with a child) the phase-out began at an income of $\$ 112,500$. For details see Figure A.2. Due to the phase-out provisions, singles (couples) above $\$ 99,000(\$ 198,000)$ did not qualify for a rebate. In Figure A.3, we plot the average size of the 
identified stimulus by users who report living in a household of a given size. In general, we see a clear upward trend in stimulus check size received as households get larger, again reinforcing the likelihood that we are truly picking up stimulus check receipt by users.

The House Ways \& Means Committee using information from the IRS estimates that 171 million people were eligible for receiving rebate payments under the CARES Act. The 171 million people split up into 145-150 million taxpayers who file returns and are were eligible for the stimulus, 20-30 million Social Security beneficiaries and SSI recipients who do not file returns, 14-15 million non-filers below the filing threshold, 6 million veterans and 500-600 thousand from the Railroad Retirement Board.

In comparison to previous stimulus payments in 2001 or 2008 , the IRS did not communicate an exact schedule for sending out the stimulus payments. An approximate schedule for the payments can still made based on the information available (see Table A.2). Taxpayers received the first payments, using direct deposit information from the tax filings from 2018 or 2019, during the week of April 13. The House Ways \& Means Committee estimates that during this first week, over 80 million Americans received payments in their bank accounts. During the following weeks the IRS continued weekly rounds of direct deposits to those who provided direct deposit information through the website of the IRS. All taxpayers who had not registered their bank account information by May 13 received their stimulus payment as paper checks. The issuing and mailing of paper checks started in the week of April 20. Checks were mailed to those with the lowest incomes first. The checks were sent out at a rate of 5 million checks per week. At this rate mailing the checks took until the end of August.

By the end of April and beginning of May, Social Security retirement, survivor and disability insurance (SSDI) beneficiaries who did not file tax returns in 2018 or 2019 received their payments via direct transfer (99 percent of Social Security beneficiaries). Adult Supplemental Security Income (SSI) recipients received their payments by early May, in the same way, they received their normal benefits (see AARP). Banks like e.g. the Bank of America and Wells Fargo allowed customers to deposit their checks using mobile solutions to make the stimulus available during the physical lockdown period and to reduce delays. Wells Fargo also allows non-customers to cash in checks at no-fees charged. As of May 8, 2020 CNN reported that more than 130 million eligible people had already received their stimulus payment. This lines up closely with the fraction 
receiving payments in our sample.

In addition to the economic stimulus package, the CARES Act made two additional provisions that are relevant. People who filed for unemployment or were partly unemployed due to the coronavirus received an additional $\$ 600$ per week on top of their state benefits, until July 31 . Whether a person is entitled to the extra money depends on whether an individual qualifies for state or other federal unemployment benefits. The extra $\$ 600$ also cover self-employed, part-time workers and gig-workers. Individuals receive their extra unemployment benefits with their state or federal benefits.

The CARES Act suspends minimum distributions from Individual Retirement Accounts (IRAs), 401(k)s, 403(b)s, 457(b)s, and inherited retirement accounts for 2020. It also waives the $10 \%$ tax penalty for early distributions of up to $\$ 100,000$ retroactively by January 1, 2020 if an individual, their spouse, or dependent others is hit by negative consequences of the COVID-19 pandemic.

Figiure A.4 presents a placebo exercise. We show spending for individuals in April who did not receive stimulus checks. There is no sharp untick in spending beyond day of the week effects, consistent with there not being significant measurement error in our sample. 
Table A.1: Household Composition and Stimulus Payments Under the CARES Act

Notes: This table shows statutory payment amounts for household stimulus payments under the CARES Act (for households not subject to an income-based means test).

\begin{tabular}{lc}
\hline \hline Household Composition & Expected Stimulus Payment \\
\hline Single & $\$ 1,200$ \\
Single with one child & $\$ 1,700$ \\
Single with two children & $\$ 2,200$ \\
Single with three children & $\$ 2,700$ \\
Single with four children & $\$ 3,200$ \\
Couple & $\$ 2,400$ \\
Couple with one child & $\$ 2,900$ \\
Couple with two children & $\$ 3,400$ \\
Couple with three children & $\$ 3,900$ \\
Couple with four children & $\$ 4,400$ \\
\hline \hline
\end{tabular}


Table A.2: The Timing of the CARES Act Stimulus Payments of 2020

Notes: The table is based on information from The House Ways \& Means Committee. The table displays payments disbursed by end of week dates (Fridays). Payments received counts the number of individuals.

\begin{tabular}{|c|c|c|c|c|}
\hline \multicolumn{2}{|c|}{$\begin{array}{l}\text { Payments } \\
\text { by electronic funds transfer }\end{array}$} & \multicolumn{2}{|l|}{$\begin{array}{l}\text { Payments } \\
\text { by check }\end{array}$} & \multirow{2}{*}{$\begin{array}{l}\text { Payments } \\
\text { received }\end{array}$} \\
\hline Taxpayer group & $\begin{array}{l}\text { Date } \\
\text { funds } \\
\text { transferred } \\
\text { by }\end{array}$ & $\begin{array}{l}\text { Taxpayer group (if } \\
\text { no bank account } \\
\text { information } \\
\text { available) }\end{array}$ & $\begin{array}{l}\text { Date } \\
\text { checks } \\
\text { received by }\end{array}$ & \\
\hline $\begin{array}{l}\text { Direct deposit } \\
\text { information on file }\end{array}$ & Apr 17 & & & 80 mil. \\
\hline $\begin{array}{l}\text { Registered direct } \\
\text { deposit information } \\
\text { with IRS until Apr } 17\end{array}$ & Apr 24 & $\begin{array}{l}<10 \mathrm{k} \\
\text { gross income }\end{array}$ & Apr 24 & \\
\hline $\begin{array}{l}\text { Registered direct } \\
\text { deposit information } \\
\text { with IRS until Apr } 24\end{array}$ & May 1 & $\begin{array}{l}10 \mathrm{k}-20 \mathrm{k} \\
\text { gross income }\end{array}$ & May 1 & \\
\hline $\begin{array}{l}\text { Registered direct } \\
\text { deposit information } \\
\text { with IRS until May } 1\end{array}$ & May 8 & $\begin{array}{l}20 \mathrm{k}-30 \mathrm{k} \\
\text { gross income }\end{array}$ & May 8 & 130 mil. \\
\hline $\begin{array}{l}\text { Registered direct } \\
\text { deposit information } \\
\text { with IRS until May 13 }\end{array}$ & May 15 & $\begin{array}{l}\text { 30k - 40k } \\
\text { gross income }\end{array}$ & May 15 & \\
\hline \multirow{4}{*}{\multicolumn{2}{|c|}{$\begin{array}{l}\text { Website for registering direct } \\
\text { deposit information closed on } \\
\text { May } 13\end{array}$}} & $\begin{array}{l}40 \mathrm{k}-50 \mathrm{k} \\
\text { gross income }\end{array}$ & May 22 & 152 mil. \\
\hline & & $\begin{array}{l}50 \mathrm{k}-60 \mathrm{k} \\
\text { gross income }\end{array}$ & May 29 & \\
\hline & & $\begin{array}{l}60 \mathrm{k}-70 \mathrm{k} \\
\text { gross income }\end{array}$ & Jun 05 & \\
\hline & & $\begin{array}{l}\text { Further increments } \\
\text { of } 10 \mathrm{k} \text { (= } 5 \mathrm{mil} . \\
\text { checks })\end{array}$ & $\begin{array}{l}\text { Weekly } \\
\text { until } \\
\text { August } 28\end{array}$ & $\begin{array}{l}171 \text { mil. } \\
\text { (expected) }\end{array}$ \\
\hline
\end{tabular}




\section{Figure A.1: Example of Notification Letter for Direct Deposit Transfer}

Notes: This figure shows an example of a notification letter for stimulus payments.

\section{Your Economic Impact Payment Has Arrived}

My Fellow American:

Our great country is experiencing an unprecedented public health and economic challenge as a result of the global coronavirus pandemic. Our top priority is your health and safety. As we wage total war on this invisible enemy, we are also working around the clock to protect hardworking Americans like you from the consequences of the economic shutdown. We are fully committed to ensuring that you and your family have the support you need to get through this time.

On March 27, 2020, Congress passed with overwhelming bipartisan support the Coronavirus Aid, Relief, and Economic Security Act (CARES Act), which I proudly signed into law. I want to thank the United States House of Representatives and the United States Senate for working so quickly with my Administration to fast-track this $\$ 2.2$ trillion in much-needed economic relief to the American people.

This includes fast and direct economic assistance to you.

I am pleased to notify you that as provided by the CARES Act, you are receiving an Economic Impact Payment of S by direct deposit. We hope this payment provides meaningful support to you during this period.

Every citizen should take tremendous pride in the selflessness, courage and compassion of our people. America's drive, determination, innovation and sheer willpower have conquered every previous challenge---and they will conquer this one too. Just as we have before, America will triumph yet again---and rise to new heights of greatness.

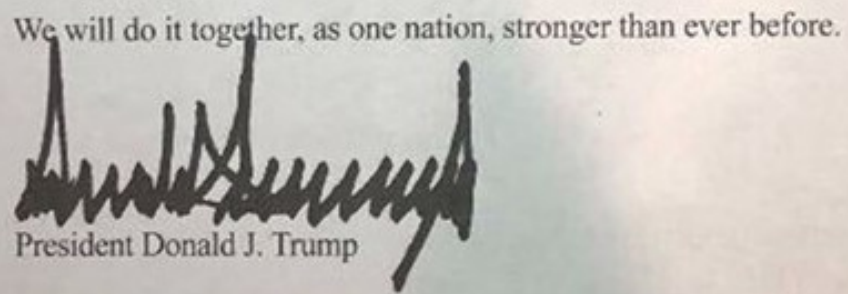

For more information on your Economic Impact Payment, please visit IRS.gov/coronavirus or call 800-919-9835. 
Figure A.2: CARES Act Economic Relief

Notes: This figure shows the expected stimulus payment for different household compositions and income levels. Source: Coronavirus Aid, Relief and Economic Security Act.

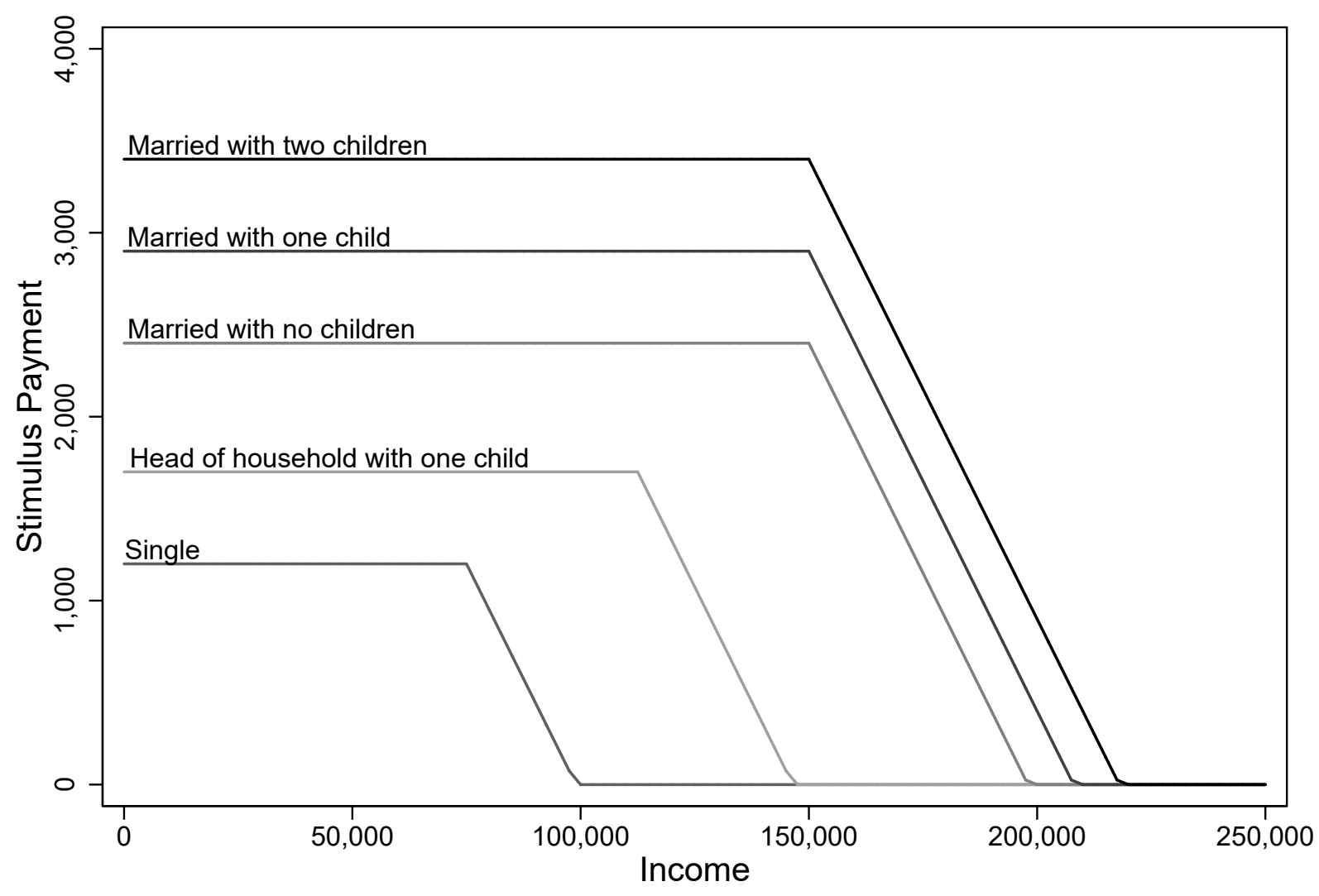

Source: Coronavirus Aid, Relief and Economic Security Act 
Figure A.3: Stimulus Amount Received by Household Size

Notes: This figure shows the average stimulus amount for users receiving stimulus checks, by self-reported household size. Source: SaverLife.

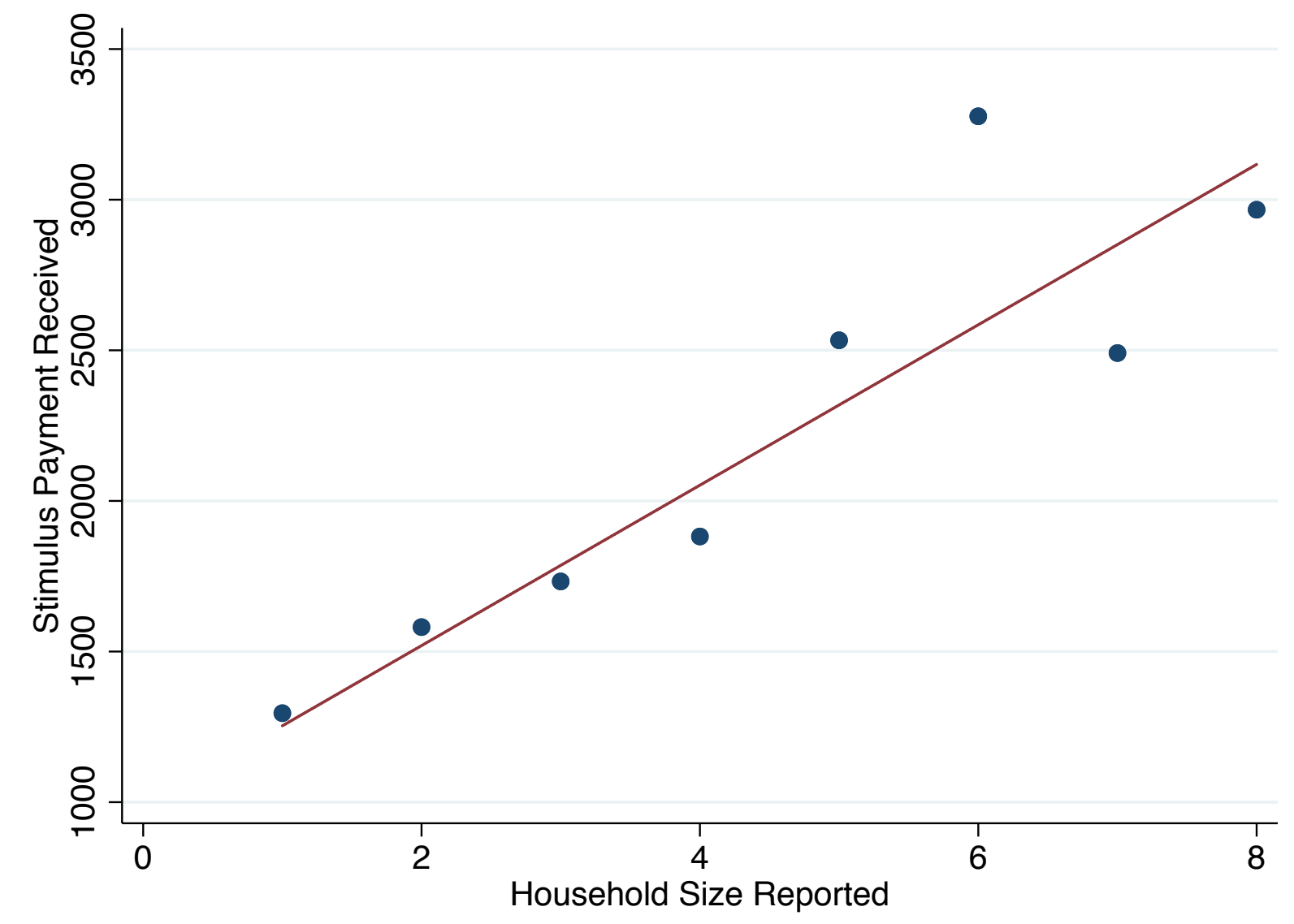




\section{Figure A.4: Mean Spending in April for Individuals Not Receiving Payment- Raw Spending}

Notes: This figure shows mean daily spending in April for individuals who did not receive payments in that month. Sample includes only users who do not receive a stimulus payment during our sample period. The vertical axis measures spending in dollars, and the horizontal axis shows the date. Shaded days represent weekends for the majority of stimulus-recipients who receive their payment on Wednesday April 15th. The graph is based on data from SaverLife.

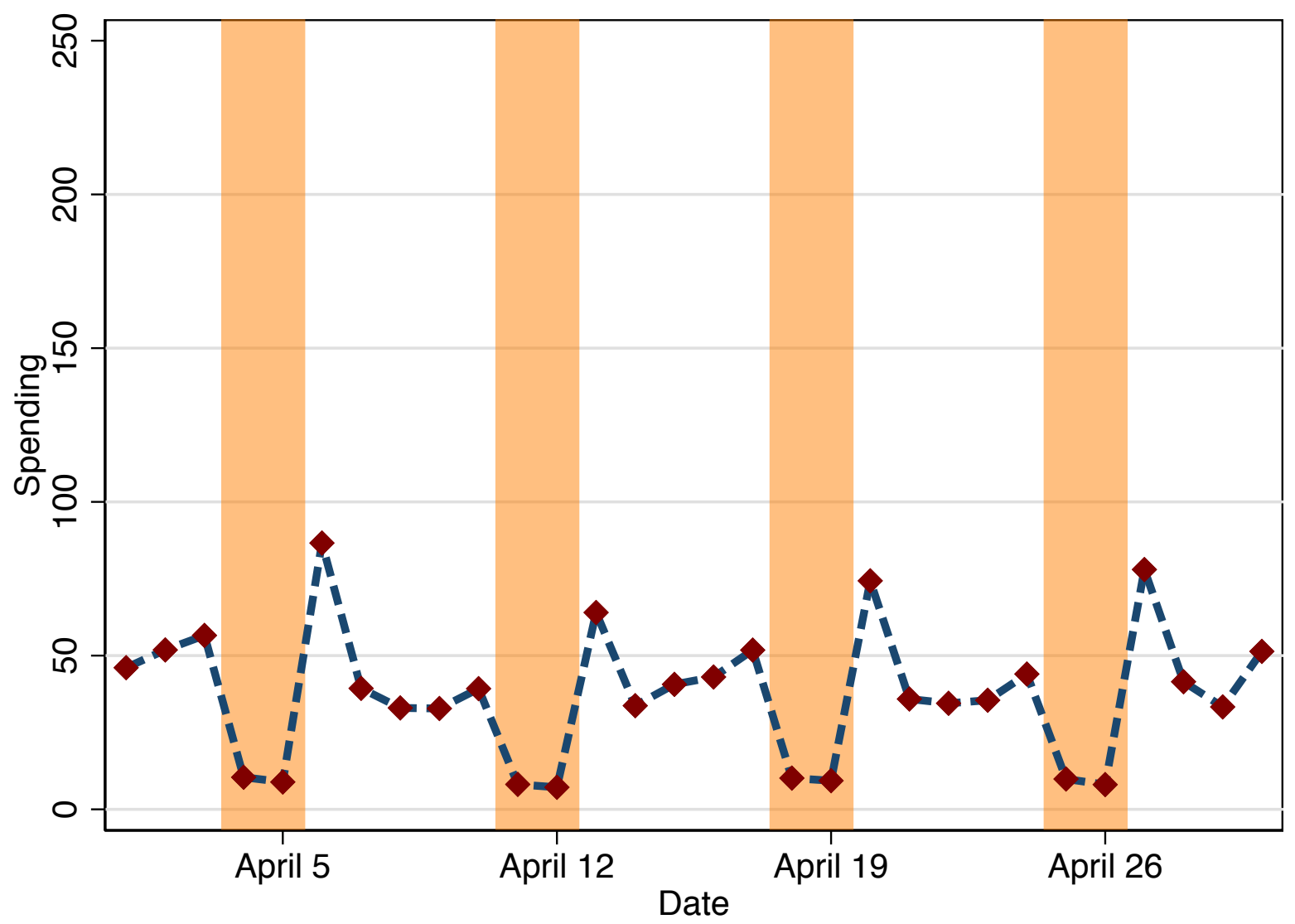

